\title{
Morpheme-based approach versus word-based approach: classifying derivative words with respect to their bases
}

\section{Морфемно-ориентированный подход в противоположность лексемно-ориентированному: классификация производных слов по отношению к их основе}

\author{
Fadhel Abbas Shalal ${ }^{1}$
}

Published online: 29 May 2018

(C) The Author(s) 2018

\begin{abstract}
Difficulties in classifying words as to their morphological source cause us to question whether such a classification should be implemented through a linear morphemic or a whole-word approach. The present paper presents an analysis of which of these approaches could be the most viable account for cases in which the derivative form reflects the following: 1) multiplicity of potential bases; 2) semantic/orthographic match with the base; and 3 ) heterogeneity of form / meaning correspondence. The morphemic approach seems acceptable when morphemes are organised in a linear arrangement, such as демократ / $\mathrm{d}^{\mathrm{j}} \mathrm{Im} \mathrm{I}^{\prime} \mathrm{krat} /$ 'democrat (m.)' > демократка /d Ime'kratkə/ 'democrat (f.)', etc. This facilitates identifying the base form, which is демократ. However, this approach cannot be generalised over other formations that show a mismatch of form and meaning between the derivative elements and their bases as found with, e.g., бельй /' $\mathrm{b}^{\mathrm{j}} \mathrm{el} \mathrm{\textrm {j }} /$ ' white' > белка /' $\mathrm{b}^{\mathrm{j}} \mathrm{elkə/}$ ' 'squirrel'. Hence, we argue that the word-based approach is possibly better utilised in this cases.
\end{abstract}

Аннотация Трудности по классификации слов по отношению к их морфологическим источникам побуждают нас задаться вопросом, следует ли при этой классификации руководствоваться морфемным или лексемным подходом. В настоящем докладе представлен анализ того, какой из этих подходов может быть наиболее пригодным для случаев, когда производная форма отражает следующее: 1) множественность потенциальных основ; 2) семантическое/орфографическое совпадение с основой; 3) неоднородность соответствия формы и значения. Морфемный подход представляется приемлемым, когда морфемы организованы линеарно, подобно таким словам, как демократ > демократка и т.д. Это облегчает нахождение основной формы демократ. Однако вследствие несоответствия формы и значения между некоторыми производными элементами и их основами, как например, белый > белка, этот подход нельзя использовать универсально. В связи с этим мы выступаем за применение лексемного подхода в таких случаях.

F.A. Shalal

fashalal1@sheffield.ac.uk

1 School of Languages \& Cultures, Russian \& Slavonic Studies, Sheffield University, Sheffield, Great Britain 


\section{Introduction}

Morphological analysis can be defined as a linguistic technique that investigates the morphological structure of a word. It provides an explanation of the participation of different components in forming a given word. This helps to classify words according to their base which might be a noun, a verb, an adjective, etc. (Shanskii 1968, p. 11).

Difficulties in classifying words as to their morphological source cause us to question whether such a classification should be implemented through a linear morphemic or a wholeword approach. We need a viable account for cases in which the surface form reflects the following: 1) multiplicity of potential bases, 2) semantic / orthographic match with the base, and 3 ) heterogeneity of form / meaning correspondence. The morphemic approach seems acceptable when morphemes are organised in a linear arrangement as it facilitates the identification of the base form. However, this approach cannot be generalised over other formations due to specific reasons which will be discussed in Sect. 4.2.

Hence, we argue that the word-based approach is possibly of more use for this classification. This approach utilises the following criteria: 1) the base form must be closely semantically related to the surface form (болгарин /bel'gar' $\mathrm{In} /$ 'Bulgarian (m.)' > болгарка /bel'garkə/ 'Bulgarian (f.); мыть /'mit'/ 'to wash' > мойка /'mojkə/ 'washing'; аптека /ер't'ekə/ 'pharmacy' > аптеика /ер't'etckə/ 'first aid kit'; however, there are counterexamples in which significant semantic differences are allowed (белый /'b'eltj/ 'white' > белка /'bjelkə/ 'squirrel'); and 2) a surface form is generated by similarity to other surface forms stored in memory; sometimes the relationship between the base form and the surface form is one of extension (демократ / $\mathrm{d}^{\mathrm{j}} \mathrm{Ime}$ ' $\mathrm{krat} /$ 'democrat (m.)' > демократка /d'ime'kratkə/ 'democrat (f.)'; дипломат /d'iple'mat/ 'diplomat (m.)' > дипломатка /d ${ }^{\mathrm{j}}$ Iple'matkə/ 'diplomat (f.)') and sometimes the relationship is more complex, what might in other approaches be termed subtractive morphology (болгарин > болгарка); mutation (аптека > аптеика); or allomorphy (мьть > мойка). The word-based approach, thus can cover all linguistic perspectives manifested by the suffix $\{+\kappa(a)\}$ in which other approaches exhibit problems; the phonological and semantic identity of words is possibly better described by this approach. This paper therefore seeks to demonstrate the validity of the word-based model in classifying words that contain the above suffix. This provides support for our main hypothesis, because the word-based approach is regarded as a main pillar of the Word and Paradigm (WP) model.

We predict that the word-based approach represented by the WP offers the best explanation for the description of $\{+\kappa(a)\}$ and gives a more convincing explanation for linguistic phenomena associated with the suffix $\{+\kappa(a)\}$ than other approaches, particularly a morpheme-based one described by the Item and Arrangement model (IA) or a process-based one described by the Item and Process model (IP).

This paper contains three major points. Firstly, we investigate an appropriate method for classifying words structured as follows: The complexity of classifying words (Sect. 2.1); Analysis of the above complexity (Sect. 2.2); A proposed method of classification (Sect. 2.3); Constraints of the above method (Sect. 2.4); and Support for the proposed method (Sect. 2.5). Secondly, the morphological classification of words with the morpheme $\{+\kappa(a)\}$ is explored in the following sections: $\{+\kappa(a)\}$ as a part of the word root (Sect. 3.1); Compound suffixes (Sect. 3.2); and Words that contain the suffix $\{+\kappa(\mathrm{a})\}$ (Sect. 3.3). Lastly, a discussion is introduced which highlights issues raised in this exploration: The complexity of the suffix $\{+\kappa(\mathrm{a})\}$ (Sect. 4.1); Problems found during applying different models (Sect. 4.2); Approaches that can be rejected as a result of the analysis of $\{+\kappa(a)\}$ formations (Sect. 4.3); Comparisons based on the analysis of $\{+\kappa(\mathrm{a})\}$ formations (Sect. 4.4). Section 5 presents a summary of the analysis. 


\section{Finding an appropriate method for classifying words}

\subsection{The complexity of classifying words}

Tracing the base of a word is possibly not a straightforward process in Russian since a word may have multiple bases. This causes confusion when trying to choose a specific variant in comparison to potential other ones. For example, the word гранка /'grankə/ 'small border, edge' has various potential bases, such as грань /'gran// 'border, edge', гранить /gre' $\mathrm{n}^{\mathrm{j}} \mathrm{it}^{\mathrm{j}}$ / 'to cut', and гранииа /gre' $\mathrm{n}^{\mathrm{j}}$ itsə/ 'border, boundary'. Subsequently, each variant is a potential base for the word гранка. Nevertheless, most explanations assign грань as the base form because гранка denotes the diminutive meaning of the former, so both the semantic and phonological correlation is found (Ušakov 1935-1940, p. 618). Similarly, the word лицемерка $/ \mathrm{l}^{\mathrm{j}} \mathrm{Its} \mathrm{I}^{\mathrm{j}} \mathrm{Im}^{\mathrm{j}}$ 'erkə/ (f.) 'hypocrite, dissembler' might be linked to лицемер $/ \mathrm{l}^{\mathrm{j}} \mathrm{Its}{ }^{\mathrm{j}} \mathrm{I}^{\prime} \mathrm{m}^{\mathrm{j}} \mathrm{er} /$ (m.) 'hypocrite, dissembler', лицемерить $/ \mathrm{l}^{\mathrm{j}} \mathrm{Its}^{\mathrm{j}} \mathrm{I}^{\prime} \mathrm{m}^{\mathrm{j}} \mathrm{er}^{\mathrm{j}} \mathrm{It}^{\mathrm{j}} /$ 'to hypocrite, dissemble', and $л и$ иемерный $/ \mathrm{l}^{\mathrm{j}} \mathrm{It} \mathrm{s}^{\mathrm{j}} \mathrm{I} \mathrm{m}^{\mathrm{j}} \mathrm{ern}: \mathrm{j}$ / 'hypocritical'. Apparently, each variant seems suitable to link the word лииемерка to it. Nonetheless, the variant лииемер seems to be most eligible to form an appropriate base for лицемерка; the semantic identity and the simplicity of morphological operations results in this decision (Akademičeskij slovar' 1958, p. 257). Interestingly, the multiplicity of morphological bases is identified by Hathout and Namer (2014, p. 181) under the concept of 'lexical under-marking'. This concept plays on the assumption that a certain derivative word might obtain multiple possible bases, as exemplified by localise which can potentially be related, whether to local, locality, or location.

Notably, a specific root in multiple surface forms can be linked to the same morphological base regardless of having different affixes, as illustrated by the word краска /'kraskə/ 'painting, dyeing' which originated from the verbal basis, that is красить /' $\mathrm{kras}^{\mathrm{j}} \mathrm{It}^{\mathrm{j}}$ / 'to paint, dye'. Other surface forms, which have the same root $\{+\kappa \mathrm{\alpha ac}+\}$, possibly originate from similar verbal bases, such as покраска /pe'kraskə/ 'paint, dye' > покрасить /pe' $\mathrm{kras}^{\mathrm{j}} \mathrm{It}^{\mathrm{j}}$ / 'to paint, dye'; закраска /ze'kraskə/ 'painting over, start painting' > закрасить /ze' $\mathrm{kras}^{\mathrm{j}} \mathrm{It}^{\mathrm{t}}$ / 'to paint over, begin to paint'; подкраска /pet'kraskə/ 'tint, colouring, touching up' > подкрасить /pet'kras ${ }^{\mathrm{j}} \mathrm{t}^{\mathrm{j}} /$ 'to tint, colour, touch up'; окраска /e'kraskə/ 'staining' > окрасить $/ e^{\prime} \mathrm{kras}^{\mathrm{j}} \mathrm{It}_{\mathrm{t}}^{\mathrm{j}} /$ 'to stain'; докраска /de'kraskə/ 'finish painting' > докрасить /de' $\mathrm{kras}^{\mathrm{j}} \mathrm{It}^{\mathrm{j}} /$ 'to finish painting'; прокраска /pre'kraskə/ 'painting over, covering with paint' > прокрасить /pre'kras ${ }^{\mathrm{j}} \mathrm{t} \mathrm{t}^{\mathrm{j}} /$ 'to paint over, cover with paint'; вылкраска /vi'kraskə/ 'painting, dyeing' > выкрасить /'vikrəs $\mathrm{s}^{\mathrm{j}} \mathrm{It}^{\mathrm{j} /}$ 'to paint, dye'; and раскраска /res'kraskə/ 'colouring' > раскрасить /res'kras ${ }^{\mathrm{j}} \mathrm{It}^{\mathrm{j}} /$ 'to colour'.

Similarly, the word носка /'noskə/ 'carrying' has been formed from the verbal base носить $/ \mathrm{ne}^{\prime} \mathrm{s}^{\mathrm{j}} \mathrm{i} \mathrm{j}$ / 'to carry'. Other derivative words, which share the same root $\{+\mathrm{Hoc}+\}$, possibly can be linked to similar verbal bases, as is the case for вноска /'vnoskə/ 'carrying in' > вносить /vne's $\mathrm{s}^{\mathrm{j}} \mathrm{i}^{\mathrm{j}} /$ 'to carry in'; подноска /ped'noskə/ 'carrying up' > подносить /pədne $\mathrm{s}^{\mathrm{j}} \mathrm{it}_{\mathrm{j}}^{\mathrm{j}}$ / 'to carry up'; переноска $/ \mathrm{p}^{\mathrm{j}} \mathrm{Ir}^{\mathrm{j}} \mathrm{I}^{\mathrm{i}}$ 'noskə/ 'transporting, transferring' > переносить $/ \mathrm{p}^{\mathrm{j}} \mathrm{Ir}^{\mathrm{j}} \mathrm{In} \mathrm{n}^{\mathrm{j}} \mathrm{s}^{\mathrm{j}} \mathrm{t}^{\mathrm{j}}$ / 'to transport, transfer'; разноска /rez'noskə/ 'delivery, distribution' > разносить /rəzne's $\mathrm{s}^{\mathrm{j}} \mathrm{t}^{\mathrm{j}} /$ 'to deliver, distribute'; поноска /pe'noskə/ 'carrying for a while' > поносить /pəne' $\mathrm{s}^{\mathrm{j}} \mathrm{i} \mathrm{t}^{\mathrm{j}}$ / 'to carry for a while'; сноска /'snoskə/ 'pulling down, footnote' > сносить /sne' $\mathrm{s}^{\mathrm{j}} \mathrm{it}$ / ' to pull down, take down'; относка /et'noskə/ 'carrying away / off' > omносить /etne' $\mathrm{s}^{\mathrm{j}} \mathrm{it}^{\mathrm{j}}$ / 'to carry away/off'; and выноска /'vinəskə/ 'carrying out / away, taking out / away' > выносить /vtne' $\mathrm{s}^{\mathrm{j}} \mathrm{it}$ / / 'to carry out / away, take out / away'.

Also, words with an identical root $\{+\sigma p o c+\}$ and different prefixes can belong to similar verbal bases, as shown by заброска /ze'broskə/ 'throwing' > забросить $/ \mathrm{ze}^{\prime} \mathrm{bros}^{\mathrm{j}} \mathrm{It}^{\mathrm{j}} \mathrm{s}$ ' to throw'; подброска /ped'broskə/ 'throwing up [into the air]' > nодбросить /ped'bros ${ }^{\mathrm{j}} \mathrm{It}^{\mathrm{j}}$ / 
'to throw up [into the air]'; переброска $/ \mathrm{p}^{\mathrm{j}} \mathrm{Ir}^{\mathrm{j}}{ }_{\mathrm{I}}$ 'broskə/ 'throwing over, transfer, shift' > перебросить $/ \mathrm{p}^{\mathrm{j}} \mathrm{Ir}^{\mathrm{j}}{ }_{\mathrm{I}}$ 'bros ${ }^{\mathrm{j}} \mathrm{t}^{\mathrm{j}} /$ ' 'to throw over, transfer, shift'; разброска /rez'broskə/ 'scattering' > разбросить /rez'bros ${ }^{\mathrm{j}} \mathrm{I} \mathrm{t}^{\mathrm{j}} /$ 'to scatter'; сброска /'zbroskə/ 'throwing down, dropping' > сбросить /'zbros ${ }^{\mathrm{j}} \mathrm{It}$ / 'to throw down, drop'; отброска /ed'broskə/ 'throwing back / off' $>$ отбросить /ed'bros ${ }^{\mathrm{j}} \mathrm{i} \mathrm{j}^{\mathrm{j}}$ / 'to throw back/off'; and выброска /'vibrəskə/ 'throwing out, rejection' > выбросить /'vibrəs ${ }^{\mathrm{j}} \mathrm{it} / \mathrm{j}$ 'to throw out, reject'.

On the other hand, words sharing the same root might differ in their base form. In other words, the fact that multiple surface words have the same root does not mean that all of them should belong to a similar morphological source. This is illustrated by the following words: закладка /ze'klatkə/ 'laying, filling'; закладочка /ze'kladətckə/ 'small filling'; and кладовка /kle'dofkə/ 'small pantry', which perhaps originate from different bases despite sharing the same root: $\{+$ клад+ $\}$. The first is related to a verbal base and expresses the action meaning of the verb закладывать /ze'kladıvət'/ 'to lay, put, fill', whereas закладочка belongs to the nominal base закладка and denotes its diminutive meaning; кладовка is connected to the adjectival base кладовый /kle'dovij/ 'pantry, store' and denotes its diminutive meaning. There are still the examples of милка /' $\mathrm{m}^{\mathrm{j}} \mathrm{ilkə/}$ 'beloved, sweetheart' and милочка /'milətckə/ 'dear, darling girl'. These words despite having the same root $\{+$ мил +$\}$, differ with respect to their morphological base word. The first one belongs to the adjectival base милый /' $\mathrm{m}^{\mathrm{j}} \mathrm{iltj} /$ 'nice, lovely, sweet' which expresses a similar meaning to its base form, while the second one has a denominal base милка which denotes its affectionate meaning.

\subsection{Analysis of the above complexity}

Tracing the base form seems problematic, especially with the multiplicity of morphological sources. The following question arises here: What leads us to choose the word грань as an appropriate base for the word гранка although there are multiple other potential bases to which гранка can be linked, such as гранить, and гранииа. At the same time, what is the reason for determining лицемерка to be morphologically affiliated with лицемер despite the fact that other words, such as лицемерить, and лицемерный seem suitable sources for the above word. Similarly, why is it that words that share an identical root, such as краска, покраска, закраска, подкраска, окраска, докраска, прокраска, выкраска, and раскраска; носка, вноска, подноска, переноска, разноска, поноска, сноска, относка, and выноска; and заброска, подброска, переброска, разброска, сброска, отброска, and выброска belong to the same (verbal) base despite differing prefixally. Conversely, other words share the same root, such as закладка, закладочка, and кладовка, and милка and милочка, and yet they differ in their base.

This implies we need to discover a straightforward method which offers solid criteria to affiliate surface words to their morphological base. This method should enable us to explain any divergence and match in terms of phonology and semantics between derivative words. Accordingly, we launched a search in order to find the most suitable method for the above classification.

\subsection{A proposed method of classification}

The semantic connection can be a crucial factor in tracing the morphological base of derivative words. This notion is supported by Bybee (1985, p. 13) and her proposal of the concept of 'relevance', which she defines as follows: "A meaning element is relevant to another meaning element if the semantic content of the first directly affects or modifies the semantic content 
of the second". In this sense, Rastle and Davis (2008, p. 943) also indicate that morphological structure is guided by semantic knowledge. This supposes that complex words are componentially represented, and that word structure is generally viewed within the context of semantic meaning.

Actually, the semantic connection might provide plausible outcomes for choosing a specific word class to be a suitable base for a given surface word despite having multiple potential base forms. This gives an accurate explanation as to why, for example the word гранка has been derived from the word грань, and not from гранить ог гранииа as explained earlier, and also, why the word лицемерка has been derived from лицемер and not from either лицемерить ог лииемерный.

In this regard, it appears logical that words sharing the same root, such as краска, покраска, закраска, etc., носка, вноска, подноска, etc., and заброска, подброска, переброска, etc. belong to the same verbal base since all of them denote the action meaning of their base word (the verb). Conversely, other words that share the same root, such as закладка, закладочка, and кладовка, as well as милка and милочка differ as to their morphological base. This can be explained by the disparity of meaning / function by which they are linked to the base word. Thus, закладка has a verbal base (закладывать) because it expresses the action meaning of the latter (Ušakov 1935-1940, p. 946), whereas кладовка belongs to an adjectival base кладовый because it provides the diminutive meaning of the latter (Ožegov and Švedova 1995, p. 270). Similarly, милка has an adjectival base because its meaning is so close to милый (Ušakov 1935-1940, p. 213); and милочка possibly belongs to a nominal base since its meaning denotes the affectionate meaning of милка (Akademičeskij slovar' 1958, p. 369).

\subsection{Constraints of the above method}

Classifying words depending on semantic correlation seems practical when attempting to match surface words with their morphological base. However, the controversy arises when encountering surface words which have diverged in meaning from their base. Consequently, it is questionable how we can trace the source of these words. For example, описка /e $\mathrm{p}^{\mathrm{j}}$ iskə/

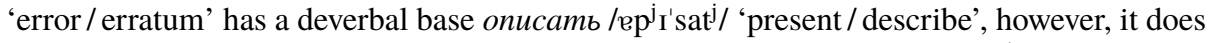
not express any semantic connection to the latter. Similarly, the word белка /' b elkə/ 'squirrel' possibly originated from бельй /' $\mathrm{b}^{\mathrm{j}}$ elij/ 'white', and yet it does not share semantic elements with the latter.

Miceli and Caramazza (1988, p. 25) point out that word meaning may be subject to alteration while derivation is taking place. Similarly, Shanskii (1968, p. 144) notes that the relationship between the parent and derivative stem can be subject to disruption, with the derivative word ceasing to relate to its parent stem in meaning. Shanskii advanced example words like красный /'krasn+j/ 'red' and работа /re'botə/ 'work' which can reflect this disruption. These examples express different meaning compared to their origins which are краса /kre'sa/ 'beauty' and раб /'rap/ 'slave'. This heterogeneity of meaning leads some scholars, such as Jacob, Fleischhauer and Clahsen (2013, p. 930) to argue that "morphological facilitation cannot be explained in terms of the convergence of semantic and orthographic / phonological codes".

Hence, how do we decide that описка originated from описать; белка from бельй; красный from краса; and работа from раб despite the fact that the semantic connection is lost? To explain this, the word-based approach hinges on the next concept: words and their connection. This connection is not only represented by semantic correlation, but is also seen by phonological similarity that exists between the base and surface form. This possibly explains why the above words are morphologically linked to words which differ in meaning. 
Interestingly, multiple works dedicated to examining the processing of morphological material by readers might be used as evidence for how we can best describe the relationships between related words. For example, McCormick, Rastle, and Davis (2008, p. 308) point out that word recognition is stipulated by morpho-orthographic and semantic connections. The former can be regarded as the reflection of the early stage of visual word processing, while the latter is used to reflect the central semantic component accessed later in processing. So that in written language, recognising a base form is associated with two factors: 1) morphoorthographic; and 2) semantic connection.

In this regard, other scholars (e.g. Rastle, Davis, Marslen-Wilson, and Tyler 2000; Longtin, Segui, and Hallé 2003; Rastle and Davis 2003; Rastle, Davis, and New 2004; Longtin and Meunier 2005) have emphasised the morphoorthographic factor, stating that associating derivative words with their base relies on the accessibility of morphological surface structures. Rastle and Davis (2008, p. 942) consider visual word processing to be involved in word recognition, such as safe $>$ safety $>$ unsafety. The earliest theoretical approach (Taft and Forster 1975) proposed that morphological decomposition as achieved by analysing sublexical orthographic data. Thus, this approach is based on a morpho-orthographic notion; it assumes that a visual lexical connection plays an essential role in the linking process whether there is semantic relevance, such as dark $>$ darkness or pseudo-morphological relatedness in particular corn > corner. Therefore, it becomes clear why Antić (2010, p. 21) mentions only that a word-based model is suitable for "representing a word with identical parts, but different overall meaning". This possibly explains why derivative words may diverge in meaning with their base words. Also, it becomes obvious why scholars, such as Shanskii $(1968$, p. 6) posit that a correct and precise assignment of a morphological structure is impossible without taking into account the correlation either phonologically or semantically between the parent and derivative stem. This correlation is a fundamental principle of the classifiction of words according to their morphological source.

\subsection{Support for the proposed method}

Semantic correlation plays a pivotal role in linking new surface words to their morphological base. This point has been emphasised by Vinogradov (1951, p. 9) who considered the possibility of associating a certain word with its morphological base to be dependent in many cases upon the semantic property of that word. This facilitates tracing the source of a certain derivative word by relying on the semantic association with its base word. Regarding that, Shanskii (1968, p. 159) reports that the morphological structure of a given word depends on its semantic meaning. Shanskii exemplified this point by adducing the word nисатель $/ \mathrm{p}^{\mathrm{j}} \mathrm{I}^{\prime} \mathrm{sat}^{\mathrm{j}} \mathrm{I}^{\mathrm{j}}$ / 'writer' in which the suffix $\{+$ тель $\}$ serves to create the nominal agent of the verb nuсать $/ \mathrm{p}^{\mathrm{j}} \mathrm{I}^{\prime}$ sat $\mathrm{j}^{\mathrm{j}}$ / 'to write'. Subsequently, the meaning / function of this suffix is derived from the meaning of the base word. Also, Rastle, Davis, and New (2004, p. 1091) indicate that the latest theories of morphological processing have embraced the conceptualisation of morphology (e.g. Marslen-Wilson, Tyler, Waksler, and Older 1994; Rueckl and Raveh 1999; Giraudo and Grainger 2000; Plaut and Gonnerman 2000; Davis, van Casteren, and MarslenWilson 2003; Gonnerman, Seidenberg, and Andersen 2007). This concept suggests that lexical representations interact with morphemic constituents of complex words when a semantically transparent relationship existed between the base and surface word. Therefore, complex words with the 'semantically transparent' feature can be observed if the meaning of complex form results from the meaning of their constituents (e.g. the meaning of писатель is derived from morphemic elements of писа[ть] plus тель). Complex words can also have a 'semantically opaque' relationship if they are not related to their constituent meaning (e.g. the meaning of the word описка is not related to its constituents meaning: опис[ать]+ка). 
The 'A-Morphous' account proposed by Anderson (1992) offers another explanation for the relationship between meaning and form. A word meaning is computed according to its semantic functions with respect to derivational rules. Therefore, the semantic meaning may control the derivational relations of the internal structure of words. Similarly, the 'Network Morphology' account proposed by Bybee (1985) is regarded as the most developed theory in terms of the word-based model. Derivative words are connected to their base words; this connection is manifested in two ways: semantically and phonologically. When this connection parallels in a word, it is easy to identify the identical semantic and phonological parts of a word so that this connection may be used as a tool to see the level of strength between the base and the derivative word. The concept of 'Degree of relatedness' is used by Bybee (1988, p. 126) to characterise how closely words are connected. A slightly similar theory to the one above is called 'Lexical Relatedness Morphology' (Stump 1994), which is considered to be the most developed theory in terms of paradigm-based models. This theory deals with two elements: words and their relationships. As far as words are related to each other, whether lexically or semantically, a paradigm is created to organise this relationship. The paradigm is represented by the base word and includes new derivative formations. A similar concept is also represented by the theory of 'Construction Grammar' (e.g. Fillmore 1988; Östman and Fried 2005; Croft and Cruse 2004; Evans and Green 2006; Goldberg 2006). Its basic idea is to associate the form of a word with its meaning at the word level. Therefore, the semantic connection might be used as a tool to trace the morphological sequence of words during the word formation process.

\section{Morphological classification of $\{+\kappa(a)\}$}

We counted 7365 words formed with the morpheme $\{+\kappa(\mathrm{a})\}$, relying on data extracted from the Obratnyj slovar' russkogo jazyka (Lazov 1974) — a retrograde dictionary of Russian. Notably, this significant quantity does not include only those words in which $\{+\mathrm{K}(\mathrm{a})\}$ appears as the only derivational suffix. Compound suffixes (e.g. $\{+$ ашка $\},\{+$ очка $\},\{+$ овка $\}$, etc.) and words in which the morpheme $\{+\kappa(\mathrm{a})\}$ is an essential part of the stem, are included in the above figure (7365). A new comprehensive classification of these words, based on three categories, will be introduced below.

\section{$3.1\{+\kappa(a)\}$ as a part of the word root}

The morpheme $\{+\kappa(a)\}$ in the formation of some words might belong to the root of the word and would not be considered to be a derivational suffix. These words are considered to be non-derived words. This means that they do not have any derivational base. This can be seen, for instance with the word наука /ne'ukə/ 'science' in which $\{+\kappa(\mathrm{a})\}$ belongs to its root. We counted 98 such non-derived words; they vary in their class, so they are divided into the following groups:

1. Nouns as exemplified by аптека /ер' $\mathrm{t}$ 'ekə/ 'pharmacy'; рука /rv'ka/ 'hand'; etc.

2. Adverbs as illustrated by изредка /'izr ${ }^{\mathrm{j}} \mathrm{Itkə/}$ 'occasionally'; слегка /s ${ }^{\mathrm{j}} \mathrm{IX}$ 'ka/ 'slightly'; etc.

3. Interjections as shown by ну-ка /'nu-kə/ 'now! / come!'; эврика /'عvr ${ }^{\mathrm{j}} \mathrm{rkə/}$ 'eureka!'; etc.

4. Conjunctions as found only in на-тка /nə-'tka/ 'here you are!'; and эка /'عkə/ 'what!'. 


\subsection{Compound suffixes}

The intuition of the speaker may not distinguish between words formed by the suffix $\{+\kappa(a)\}$ and other rival suffixes which share similar phonemic material. At first glance, when encountering words such as блошка /'bloșkə/ 'small flea' and ладошка /le'doșkə/ 'small palm', the speaker may decide that these words contain only one suffix, $\{+\kappa(a)\}$. However, this is not the case, the semantic and phonological correlation between the parent and derivative words shows that блошка relates to the word блоха /ble'xa/ 'flea' to indicate the diminutive meaning (Akademičeskij slovar' 1957, p. 116), while the latter contains an additional suffix $\{+$ ошка $\}$ and relates to the word ладонь /le'donj/ 'palm', denoting a diminutive of it (Ožegov and Švedova 1995, p. 312). Subsequently, it was noticed that words with compound suffixes that include $\{+\kappa(a)\}$ number 1456; these suffixes are divided into the following:

1. $\{$ + ашка / ешка / ёшка / ишка / ошка / ушка / ышка / юшка / яшка $\}$

болтун /bel'tun/ 'chatter' > болтунишка /bəltu'n' $\mathrm{n}^{\mathrm{j}} \mathrm{iskə} /$ 'small chatter'; борода /bəre'da/ 'beard' > бородушка /be'rodøș

2. $\{$ +ака/ ока / ека / ёка / ика / йка / ука / ыка / юка $\}$

акробат /ekre'bat/ 'acrobat' > акробатика /ekre'bat' ${ }_{\mathrm{rkə}}$ ' 'acrobatics'; холод /'xolət/ 'cold' > холодюка /хәlə'd' $\mathrm{ukə/}$ 'very cold'; etc.

3. $\{$ +анка / енка / ёнка / инка / онка / янка $\}$

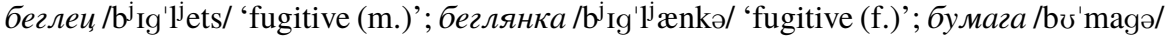
'paper' > бумажонка /bəme'zonkə/ 'scrap of paper'; etc.

4. $\{+\mathrm{a}\}$

акустик /e'kus' ${ }^{\mathrm{j}} \mathrm{t}^{\mathrm{j}} \mathrm{k} /$ 'sound technician' > акустика /e'kus $\mathrm{s}^{\mathrm{j}} \mathrm{t}^{\mathrm{j}} \mathrm{k} \mathrm{k} /$ 'acoustics'; механик $/ \mathrm{m}^{\mathrm{j}} \mathrm{I}^{\prime} \mathrm{xan}^{\mathrm{j}} \mathrm{Ik} /$ 'mechanician' > механика /m $\mathrm{m}_{\mathrm{I}}^{\mathrm{j}} \mathrm{xan}^{\mathrm{j}} \mathrm{Ikə/}$ 'mechanics'; etc.

5. $\{$ +лка / алка / олка / елка / илка / улька / ялка $\}$

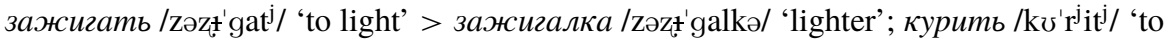

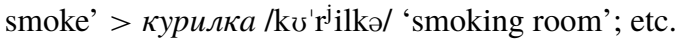

6. $\{$ +ичка/ ечка/ очка $\}$

бомба /'bombə/ 'bomb' > бомбочка /'bombətckə/ 'small bomb'; $\partial я \partial я /$ /' $\mathrm{j}^{\mathrm{j}} \mathrm{d}^{\mathrm{j}}{ }^{\mathrm{j}} /$ ' uncle' $>$ дядеика /' $\mathrm{d}^{\mathrm{j}} \mathrm{d}^{\mathrm{j}} \mathrm{it} 6 \mathrm{kə} /$ 'lovely uncle'; etc.

7. $\{+$ авка / ёвка/ овка/ ивка / явка $\}$

вор /'vor/ 'thief (m.)' > воровка /ve'rofkə/ 'thief (f.)'; пошить /pe'sit'j/ 'to sew' > noшивка /pe'sifkə/ 'sewing'; etc.

8. $\{+$ енька/ инька / онька / ынька $\}$

батя /'bat ${ }^{\mathrm{j}} \curvearrowright /$ ' dad / father' > батенька /'bat ${ }^{\mathrm{j}} \mathrm{In}^{\mathrm{j}} \mathrm{kə} /$ 'lovely dad / father'; голова /gəle'va/ 'head / mind' > головонька /ge'lovən'kə/ 'lovely head/ mind'; etc.

9. $\{$ +тка/ атка/ етка/ётка/ отка/ утка/ ютка $\}$

танк /'tank/ 'tank' > танкетка /ten'k'etkə/ 'small tank'; роза /'rozə/ 'rose' > розетка $/ \mathrm{re}^{\mathrm{j}} \mathrm{z}^{\mathrm{j}}$ etkə/ 'rosette'; etc.

10. $\{$ + арка / ерка / ёрка / орка / ирка / урка / юрка / ярка $\}$

дочь /'dot $6 /$ 'daughter' > дочурка /de'tcurkə/ 'little daughter'; этажс /I'taș/ 'floor, storey' > этажерка /Ite'z̨erkə/ 'bookcase, shelves'; etc.

11. $\{+$ аска/ еска/ иска $\}$

одаль /'odəl'j/ 'a little way away, aloof' > одалиска /еde'lisiskə/ 'odalisque'; сосать /se'sat ${ }^{\mathrm{j} /}$ 'to suck' > сосиска /se's 's iskə/ 'small sausage'; etc.

12. $\{+$ ёжка / яжка $\}$

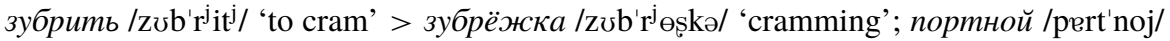
'tailor' > портняжка /pert' $n^{\mathrm{j}} \mathfrak{s} \mathrm{k} ə /$ 'a bit of tailor'; etc. 


\subsection{Words that contain the suffix $\{+\kappa(a)\}$}

Words formed with the suffix $\{+\kappa(\mathrm{a})\}$ number 5811. These words vary with respect to their morphological base, so they are derived from various parts of speech. Accordingly, they are divided into the following:

1. Words derived from nominal bases: these formations number 3165. Interestingly, the formation of these words is traditionally described using various linguistic terms: 1) simple formation: абонент /ebe' $n^{\mathrm{j} e n t / ~ ' s u b s c r i b e r ~(m .) ' ~>~ а б о н е н т к а ~ / e b e ' ~} \mathrm{n}^{\mathrm{j}} \mathrm{entkə/}$ 'subscriber (f.)'; 2) truncation: болгарин /bel'gar' In/ 'Bulgarian (m.)' > болгарка /bel'garkə/ 'Bulgarian (f.)'; 3) allomorphy: буква /'bukvə/ 'letter' > буковка /'bukəfkə/ 'small letter'; 4) mutation: бляха /'bl æxə/ 'plate' > бляшка /'bl'æsk formation: англоман /engle'man/ 'an Anglophile (m.)' > англоманка /engle'mankə/ 'an Anglophile (f.)'.

2. Words derived from verbal bases: these formations number 2091. Multiple phenomena are also observed here: 1) truncation: варить /ve' $\mathrm{r}^{\mathrm{j}} \mathrm{i}^{\mathrm{j}} /$ 'to cook / boil' > варка /'varkə/ 'cooking / boiling'; 2) mutation: выпахать /'vipəхәt'/ 'to plow' > выпашка /'vipəşkə/ 'plowing'; 3) allomorphy: гнать /'gnat'/ 'to chase/ hunt' > гонка /'gonkə/ 'chasing / hunting'; and 4) compound formation: зубочистить /zvpe't $\mathrm{t}_{\mathrm{c}} \mathrm{is}_{\mathrm{t}}^{\mathrm{j}} \mathrm{It}^{\mathrm{j}} /$ ' 'to clean teeth' > зубочистка /zvbe'tcistkə/ 'toothpick'.

3. Words derived from adjectival bases: these formations number 530; they are traditionally described using the terms: 1) simple formation: любой $/ \mathrm{l}^{\mathrm{j}} \mathrm{u}$ 'boj/ 'any' > Любка

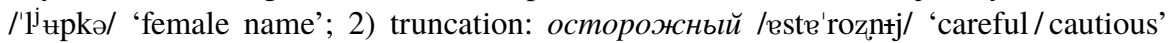
> осторожка /este'rozkə/ 'care/caution'; 3) allomorphy: нежный /'n'ez̧n+j/ 'tender/delicate' > неженка /'n' ez̧nkə/ 'sensitive person'; 4) compound formation: двух-

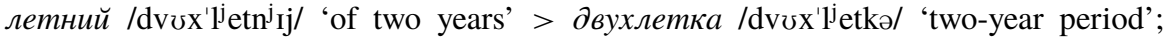
and 5) abbreviated formation: кредитный $/ \mathrm{kr}^{\mathrm{j}} \mathrm{I}^{\prime} \mathrm{d}^{\mathrm{j}} \mathrm{itn}_{\mathrm{j}} \mathrm{j} /$ 'credit' > кредитка $/ \mathrm{kr}^{\mathrm{j}} \mathrm{I}^{\prime} \mathrm{d}^{\mathrm{j}} \mathrm{itkə}$ 'credit card'.

4. Words derived from other parts of speech: these formations relate to the remaining parts of speech; they are fewer in number than the others: 1) number bases, which contribute to 16 words, such as $\partial в о е$ /'dvojə/ 'two' > двойка /'dvojkə/ 'two'; 2) adverb bases, which lead to the creation of 3 words as exemplified by авось $/ \mathrm{e}^{\prime} \operatorname{vos}^{\mathrm{j} /}$ 'perhaps / may be' > авоська /e'vos' $\mathrm{j}$ / / 'string-bag'; 3) conjuction bases, which are part of 3 words, such as буде /'bud's/ 'if / in case' > будка /'butkə/ 'box/stall/ cabin'; 4) a pronoun base, which gives rise to only one word: кой /'koj/ 'which' > койка /'kojkə/ 'cot, bed'; 5) an interjection base, which results in only one word: люли $/ \mathrm{j}^{\mathrm{j}} \mathrm{u}^{\prime} \mathrm{j}^{\mathrm{j}} \mathrm{i} /$ 'good' $>$ люлька /' $\mathrm{l}^{\mathrm{j}} \mathrm{zl}^{\mathrm{j}} \mathrm{kə} /$ 'cradle'; and 6) a preposition base, which leads to the formation of one word: кроме /'kromis I/ 'except' > кромка /'kromkə/ 'edge; list'.

\section{Discussion}

Applying the word-based model in classifying words has revealed significant issues and phenomena relating to the word formation process. This implication is discussed taking the following points into account.

\subsection{The complexity of the suffix $\{+\kappa(a)\}$}

In Russian, there are suffixes that are distinguished by the fact that they form surface words in a uniform manner. These suffixes do not display a variation of form; they keep the same 
phonological/orthographic composition. In addition, these suffixes are found with surface words derived only from a particular base as found by $\{+$ тель $\}$ and $\{+$ ость $\}$; the former is found exclusively in words with verbal bases (nисать $/ \mathrm{p}^{\mathrm{j}} \mathrm{I}^{\prime} \mathrm{sat}^{\mathrm{j}} /$ 'to write' $>$ писатель $/ \mathrm{p}^{\mathrm{j}} \mathrm{I}^{\prime} \mathrm{sat}^{\mathrm{j}} \mathrm{I}^{\mathrm{j}}$ / 'writer'), while the latter creates words derived only from adjectives (вечный

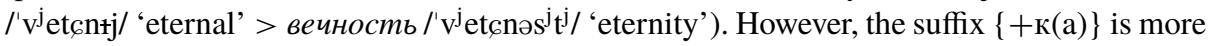
complex compared to the suffixes above. This complexity is shown in the following points:

1. The morpheme $\{+\kappa(a)\}$ generates multiple categories as displayed in Fig. 1. Many words have been created by the inclusion of compound suffixes which share the similar ending $\{+\kappa(a)\}$. Figure 2 illustrates the diversity and quantity of these suffixes. It was found that the morpheme $\{+\kappa(a)\}$ in some cases constitutes a crucial part of the root rather than as a derivational suffix. These formations are classified into different word classes which is shown in Fig. 3. Hence, words with the morpheme $\{+\kappa(a)\}$ undergo a complex formation. This complexity is represented by various categories. Therefore, at first glance, we must be cautious when saying that a specific word belongs to a certain category unless a scrutiny of morphological relatedness is made to assure accurate classification.

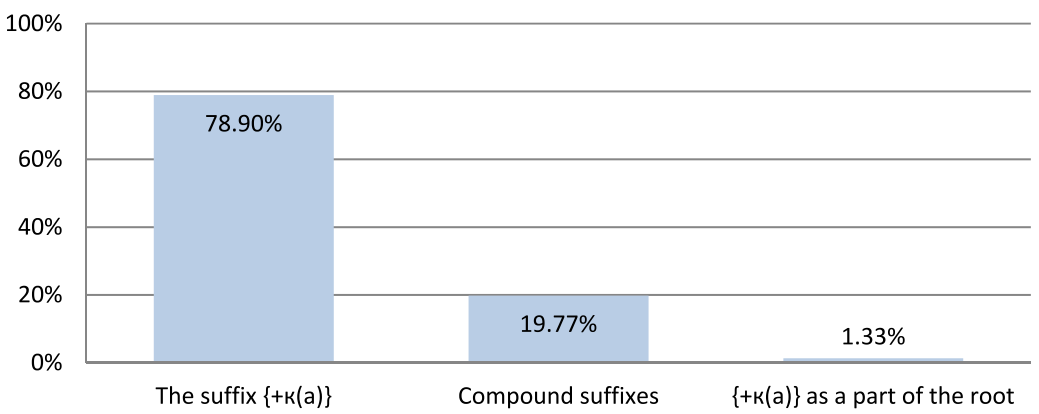

Fig. 1 Words containing the morpheme $\{+\kappa(a)\}$

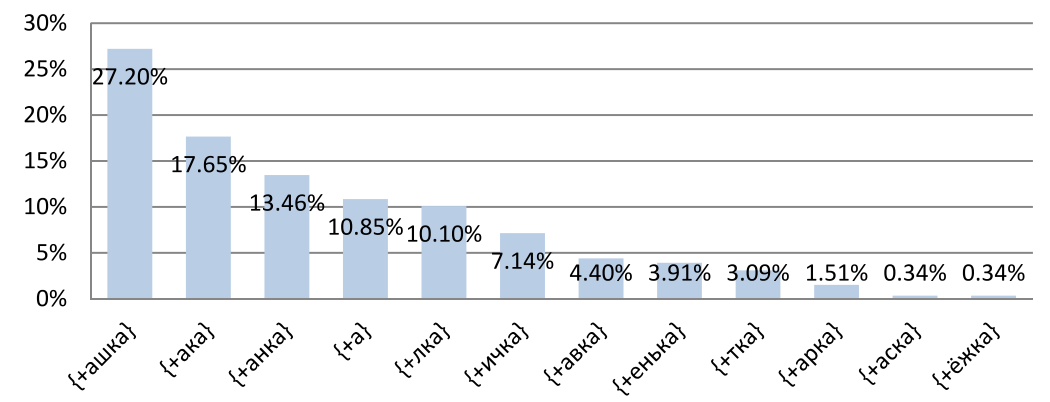

Fig. 2 Distribution of compound suffixes 


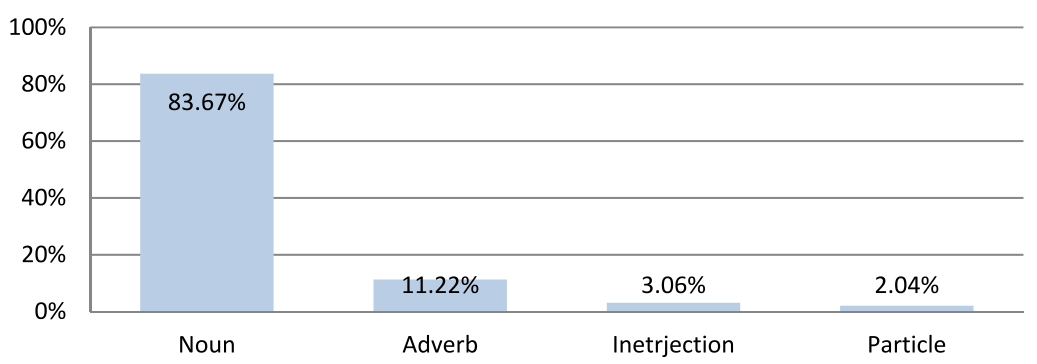

Fig. 3 Non-derived words ending in $\{+\kappa(a)\}$

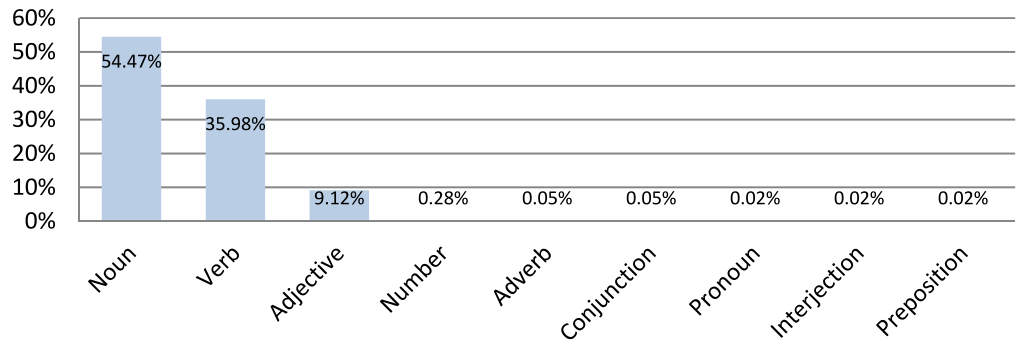

Fig. 4 Various bases of words with the suffix $\{+k(a)\}$

2. Words formed by the suffix $\{+\kappa(a)\}$ are derived from various word classes; this diversity has been stated by multiple scholars (e.g. Uluxanov 1975; Danilenko 1977; Cubberley 1994) and is shown in the Fig. 4.

The suffix $\{+\kappa(a)\}$ seems to be productive owing to its type frequency. The higher productivity of $\{+\kappa($ a) $\}$ compared to the suffixes $\{+$ тель $\}$ and $\{+о с т ь\}$ results from its ability to combine with various word classes as bases. This productivity is possibly demonstrative of the fact that "the wider and more varied the connections of a given affix with words and stems, the more productive it is, and vice versa" (Shanskii 1968, p. 69).

3. We have identified differences in the frequency of using specific affixes to form words with the suffix $\{+\kappa(a)\}$. The two types of frequency are marked 'type' and 'subtype' frequency. The former relates to the quantity of base words ending in a certain affix, while the latter indicates the contribution of these affixes in the formation of surface words that express different meanings. These meanings are divided into the following: 1) 'diminutiveness' which is assigned for diminutive formations; 2) 'feminisation' which is assigned for shifting the gender from male to female; 3) 'action' which is assigned for formations denoting an action meaning; 4) 'concreteness' which is assigned for formations indicating specific tangible objects or characteristics of certain things. The frequency of the affixes is shown in Tables 1, 2, 3 . 
Table 1 The distribution of denominal affixes

\begin{tabular}{|c|c|c|c|c|c|c|}
\hline \multirow[t]{2}{*}{ No. } & \multirow[t]{2}{*}{ Affix type } & \multirow[t]{2}{*}{ Type frequency } & \multicolumn{4}{|c|}{ Subtype frequency } \\
\hline & & & Diminutiveness & Feminisation & Action & Concreteness \\
\hline $1-$ & $\{+$ ист $\}$ & 234 & & 234 & & \\
\hline $2-$ & $\{+$ ец $\}$ & 231 & 2 & 216 & & 13 \\
\hline $3-$ & $\{+$ ина $\}$ & 199 & 175 & & & 24 \\
\hline 4- & $\{+$ ак / ик / як $\}$ & 84 & & 77 & & 7 \\
\hline 5- & $\{+$ ин / анин / янин $\}$ & 110 & 2 & 99 & & 9 \\
\hline 6- & $\{+$ ант / ент / янт $\}$ & 53 & & 53 & & \\
\hline 7- & $\{+$ ep $/$ ëp $\}$ & 54 & 1 & 48 & & 5 \\
\hline 8- & $\{+$ ица $\}$ & 49 & 38 & & & 11 \\
\hline 9- & $\{+$ ap / арь $\}$ & 33 & & 23 & & 10 \\
\hline $10-$ & $\{+\mathrm{aT}\}$ & 32 & 1 & 29 & & 2 \\
\hline $11-$ & $\{+\mathrm{au}\}$ & 10 & & 10 & & \\
\hline $12-$ & $\{+$ ник $\}$ & 5 & & 5 & & \\
\hline $13-$ & $\{+$ ищ $\}$ & 2 & & 2 & & \\
\hline
\end{tabular}

Table 2 The distribution of deverbal affixes

\begin{tabular}{|c|c|c|c|c|c|c|}
\hline \multirow[t]{2}{*}{ No. } & \multirow[t]{2}{*}{ Morpheme type } & \multirow{2}{*}{$\begin{array}{l}\text { Type } \\
\text { frequency }\end{array}$} & \multicolumn{4}{|c|}{ Subtype frequency } \\
\hline & & & Diminutiveness & Feminisation & Action & Concreteness \\
\hline $1-$ & $\{+$ +ать / ить / еть / ыть / ять / оть $\}$ & 1496 & 1 & 3 & 1337 & 155 \\
\hline $2-$ & $\begin{array}{l}\{+ \text { овать / авать / ивать/ывать / } \\
\text { евать /ёвать }\}\end{array}$ & 380 & & & 363 & 17 \\
\hline $3-$ & $\begin{array}{l}\{+ \text { ировать / аровать / еровать / } \\
\text { уровать }\}\end{array}$ & 210 & & & 208 & 2 \\
\hline 4- & $\{+$ нуть $\}$ & 7 & & & 4 & 3 \\
\hline $5-$ & $\{+$ аться/иться $\}$ & 4 & & & 3 & 1 \\
\hline
\end{tabular}

Table 3 The distribution of deadjectival affixes

\begin{tabular}{llllll}
\hline No. & Morpheme type & Type frequency & \multicolumn{2}{l}{ Subtype frequency } & \\
\cline { 4 - 5 } & & Diminutiveness & Feminisation & Action & Concreteness \\
\hline $1-$ & $\{$ +овый / евый/ ёвый $\}$ & 134 & 1 & 133 \\
$2-\quad\{+$ - & 291 & & 291 \\
\hline
\end{tabular}

Subsequently, type frequency refers to whether the participation of a specific affix is productive or not in accordance to the number of their occurrences. However, subtype frequency results in a certain affix being more predictable and representative of a certain meaning / function. Thus, on the one hand, we may consider the nominal affix $\{+$ ист $\}$ to be more productive than the affix $\{+$ и $\}$ in forming words with the suffix $\{+\kappa(a)\}$. On the other hand, we may consider the former $(\{+$ ист $\})$ to be more predictable and are more memorable than the latter $(\{+и щ\})$ for the creation of a feminine nouns ending in $\{+\kappa(a)\}$ as shown in Table 1 . 
4. Compound words contributed to the creation of words with the suffix $\{+\kappa(a)\}$. This formation can be seen in киноартист $/ \mathrm{k}^{\mathrm{j}}$ Ineer' $\mathrm{t}^{\mathrm{j}} \mathrm{ist} /$ 'film actor' $>$ киноартистка $/ \mathrm{k}^{\mathrm{j}}$ Ineer' $\mathrm{t}^{\mathrm{j}}$ istkə/ 'film actress'; two words (кино and артист) are set together to form киноартистка. However, other compounds have been formed by a combination of an abbreviated adjective with a complete noun as exemplified by физкультурка /f $\mathrm{f}^{\mathrm{j}} \mathrm{Izk} \mathrm{l}^{\mathrm{j}}$ 'turkə/

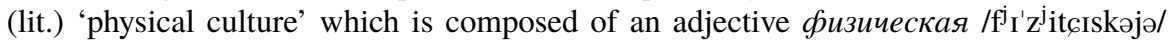
'physical' and a noun культура /kvl 'turə/ 'culture'. Notably, the formation of other compounds reflects an abbreviation of adjectives with nouns though; where a noun like комHama /'komnətə/ 'room' is dropped, coinciding with attaching the suffix $\{+\kappa(\mathrm{a})\}$ to the

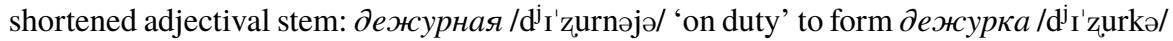
'the duty room'. Zemskaja and Šmelev (1966, pp. 58-59) indicate that this sort of formation is widely used in informal language-spoken and artistic language. Other scholars (e.g. Vinogradov, Istrina, and Barxudarov 1952; Ignatova, Lifšic, and Guseva 1960; Šmelev 1964; Potixa 1970; Townsend 1975; Ryazanova-Clarke and Wade 1999) have noticed this formation which can also be found in зачётка /ze'tcetkə/ 'record-book' (зачёт-

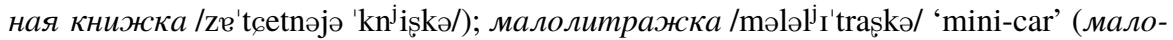

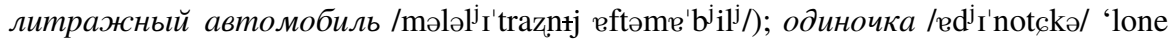

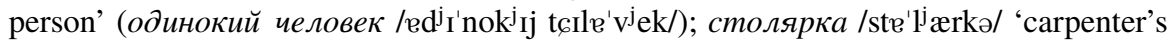
shop' (столярная мастерская /ste' $\mathrm{l}^{\mathrm{j}}$ ærnəjə məst $\mathrm{t}^{\mathrm{j}} \mathrm{rrsk}$ 'ajə/); землянка $/ \mathrm{z}^{\mathrm{j}} \mathrm{Im}^{\prime} \mathrm{j}^{\mathrm{j}}$ æn 'earth-house' (земляное жильё $/ \mathrm{z}^{\mathrm{j}} \mathrm{Iml}^{\mathrm{j}} \mathrm{I}^{\prime} n^{\mathrm{j}}$ ejə z七t $\mathrm{z}^{\mathrm{j}} \mathrm{j} \Theta /$ ), etc. Moreover, other compounds consist of acronyms of adjectives and nouns as found in комсомолеи /kәmse'molj Its/ 'member of the Young Communist League (m.)' > колсомолка /kəmse'molkə/ 'member of the Young Communist League (f.)'; in which комсомолеи means: коммунисти-

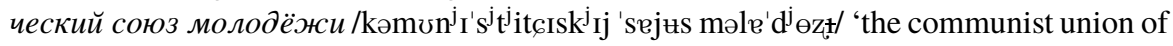
youth'. This type of formation was remarkable during the Soviet period due to the bureaucracy and the way in which journals were written in those days (Lenngren 1978, p. 47).

5. The suffix $\{+\kappa(a)\}$ seems to be unstressed in all formations. Notably, denominal words used to have a mobile stress when attaching to it, and yet others keep the same stress. To exemplify this, words like головá /gəle'va/ 'head' > голо́вка /ge'lofkə/ 'small head'; рука́ /rv'ka/ 'hand' > ру́ика /'ruţ̧kə 'small arm, handle', etc. reflect

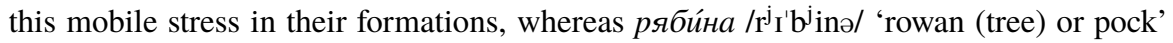
> рябйнка / $\mathrm{r}^{\mathrm{j}}{ }_{\mathrm{I}} \mathrm{b}^{\mathrm{j}}$ inkə/ 'small rowan (tree) or pock'; paбóma /re'botə/ 'work/job'> рабо́кка /re'botkə/ 'work/ job', etc. indicate that the stress remains on the same syllable. Similarly, deverbal and deadjectival words vary in terms of having a mobile stress. This can be seen in вде́лать /'vd $\mathrm{d}^{\mathrm{j}} \mathrm{el} \mathrm{t}^{\mathrm{j}} /$ 'to fit/set into' > вде́лка /'vd $\mathrm{d}^{\mathrm{j}} \mathrm{elkə/}$ 'fitting/setting

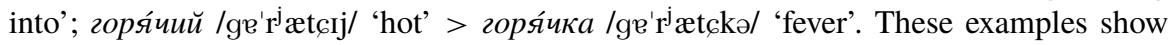
that the stress remains in the same place. However, бинтова́mь $/ \mathrm{b}^{\mathrm{j}}$ Inte' $^{\prime} \mathrm{vat}^{\mathrm{j} /}$ 'to ban-

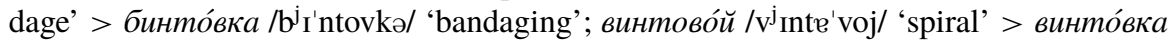
$/ \mathrm{v}^{\mathrm{j}}$ In'tofkə/ 'rifle', etc. show that the stress is moved from one place to another. Accordingly, mobile stress seems to have an illusive role; the whole issue of how to cope with stress patterns in an account of morphology is highly complex in a language like Russian. Thus, it is said that the Russian mobile stress is "free of exceptions" (Ukiah 1996, p. 701).

\subsection{Problems found during applying different models}

Rules posited to describe the process of word formation differ between the morphological models: Item and Arrangement (IA), Item and Process (IP), and Word and Paradigm (WP). This disparity is triggered by the difference in basic concepts for each one. An additive morphology is regarded as a rule for the IA model; morphemes are added one by one. Thus, classifying words according to the morphemic approach seems tolerable when the deriva- 
tional sequence of some words tends to be automatically comprehended, such as автомо-

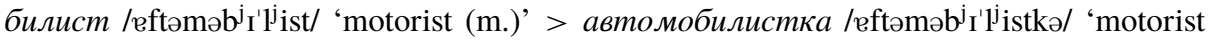

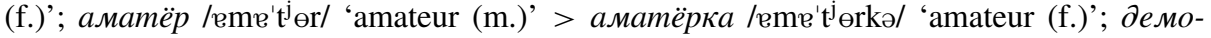
крат /d Ime'krat/ 'democrat (m.)' > демократка /d Ime'kratkə/ 'democrat (f.)'; дипломат /d Iple'mat/ 'diplomat (m.)' > дипломатка / $\mathrm{d}^{\mathrm{j}}$ Iple' matkə/ 'diplomat (f.)', etc. In these formations, putting the suffix $\{+\kappa(\mathrm{a})\}$ in a linear arrangement simply facilitates identifying the base form which is автомобилист, аматёр, демократ, and дипломат. Hоwever, this approach cannot be generalised over other formations for the following reasons:

1. Some formations reflected a mismatch of form and meaning between the base and surface word. Accordingly, relying on the arrangement of morphemes as one-to-one to trace the morphological source of words does not offer an accurate description of why certain phonemes are alternated (деревня / $\mathrm{d}^{\mathrm{j}} \mathrm{I}^{\mathrm{j}} \mathrm{r}^{\mathrm{j}} \mathrm{evn}^{\mathrm{j}}$ ə/ 'village' > деревенька $/ \mathrm{d}^{\mathrm{j}} \mathrm{Ir}^{\mathrm{j}} \mathrm{I}^{\prime} \mathrm{v}^{\mathrm{j}} \mathrm{en}^{\mathrm{j}} \mathrm{kə} /$

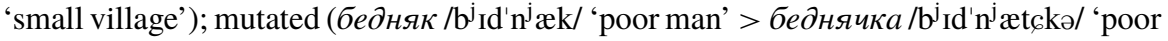
woman'); or why a given stem is truncated (беженеи /' $\mathrm{b}^{\mathrm{j}} \mathrm{ez}+\mathrm{n}^{\mathrm{j}} \mathrm{Its} /$ 'refugee $(\mathrm{m} .)^{\prime}>\sigma e$ женка /' $\mathrm{b}^{\mathrm{j}} \mathrm{ez}$ tnkə/ 'refugee (f.)').

2. The IA model presumes that the order of affixes isomorphically corresponds to morphosyntactic properties. However, this might cause problems pertaining to the correct order of morphemes according to word composition. Therefore, it is questionable whether to link the word незнакомка /n' 'known woman' or незнакомеи / $\mathrm{n}^{\mathrm{j}} \mathrm{Izne}$ 'kom' Its/ 'strange man'. If незнакомка derives from знакомка, then it opposes the main concept of the morphemic approach which juxtaposes morphemes in a linear arrangement. On the contrary, if незнакомка derives from незнакомеи, then proposing that $\{\mathrm{He}+\}$ constitutes a level 1 affix and $\{+\mathrm{\kappa}(\mathrm{a})\}$ constitutes a level 2 affix is inaccurate with respect to the commonly agreed level of affixes, which is reflected in the term 'bracketing paradoxes' (e.g. Kiparsky 1982; Pesetsky 1985; Mohanan 1986; McMahon 1994; Chialant and Caramazza 1995).

3. It appears to be difficult to distinguish between the suffix $\{+\kappa(a)\}$ and other compound suffixes (e.g. $\{+л к(a)\},\{+$ овк(a) $\},\{+$ очк(a) $\},\{+$ инк(a) $\}$, etc.) while applying the morphemic view in classifying words. Accordingly, when decomposing a certain word, there is no distinction as to whether this word is formed by the suffix $\{+\kappa(a)\}$ or other analogous suffixes; the linear arrangement of morphemes would consider all words ending in $\{+\kappa(a)\}$ as being formed only by the suffix $\{+\kappa(a)\}$. For example, the formation of both the following words: соломинка /se'lom' Inkə/ 'small straw'; and снежинка /sn' I'zinkə/ 'snowflake' would only be made apparent by the participation of the suffix $\{+\kappa(a)\}$. However, this is not the case; the former has been formed by the above suffix to denote the diminutive meaning of соломина /se'lom Inə/ 'straw', while the latter has been formed by the inclusion of another compound suffix $\{+$ инк(a) $\}$, which relies on the base form (снег /'sn $n^{\mathrm{j}} \mathrm{ek} /$ 'snow') to express its diminutive meaning. Hence, using the morphemic approach would not differentiate between the suffix $\{+\kappa(a)\}$ and other analogous suffixes.

4. It is debatable, whether the base will choose the affix or the affix will choose the base. In other words, is the suffix $\{+\kappa(a)\}$ chosen by its base or is the base determined by the above suffix. Chialant and Caramazza (1995, p. 112) point out that there are restrictions imposed by the bases which allow or prevent a particular affix to be attached to them. Regarding this, Townsend (1975, p. 175) notes that the Russian suffix $\{+$ ант $\}$ is exclusively added to foreign bases: курс /'kurs/ 'course' > курсанm /kur'sant/ 'student'. Similarly, specific suffixes are chosen to be attached to a particular base, as exemplified by $\partial e л a m b^{i p f} / / \mathrm{d}^{\mathrm{j}} \mathrm{el}^{\mathrm{i}} \mathrm{t}^{\mathrm{j}} /$

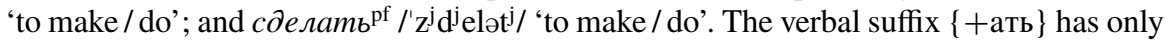
been chosen to create the imperfect / perfect form of the above verb despite the existence of other verbal suffixes such as $\{+$ ить $\}$, and $\{+$ овать $\}$. Also, Brown and Hippisley (2012, 
p. 270) note that the syntactic category of the base word can determine which affix can be attached to it.

Plag (1996, p. 776) proposes a 'base-driven' concept; he argues that affixes are selected by their bases. Plag exemplified this by listing nouns ending in the affix $\{+$ cation $\}$ which are exclusively added to verbal bases ending in the affix $\{+$ ify $\}$, such as notify $>$ notification; and identify > identification.

However, when allomorphy takes place, affixes would choose the base which possibly contradicts Plag's view. Morphemes might be pronounced in various ways depending on the phonological environment, so they acquire different phonological symbols. For example, the suffix $\{+s\}$ of the English plural form would choose its base according to the preceding sound (whether it is a sibilant, voiceless or voiced consonant). Thus, the phonological allomorph of the word roses is /iz/ since there is a sibilant sound before the suffix $\{+\mathrm{s}\}$, whereas the word cups represents the allomorph /s/ due to the existence of a preceding voiceless sound. Meanwhile the allomorph /z/ is obvious in words containing a preceding voiced consonant or a vowel, as illustrated by days and dogs.

Similarly, in Russian, there are instances in which one of the given allomorphs seems more appropriate than others for a given word. The decision of choosing a specific allomorph can be determined by the formative structure of adjacent morphs. For instance, the suffix $\{+$ ств $(0)\}$ has another allomorph, that is $\{+$ еств $(0)\}$. The latter usually appears only after morphs that end in hissing (шипящие) phonemes as illustrated by владыцество /vle'ditcistvə/ 'domination'; and изящество /I'zjæc: finement, elegance'. Conversely, the former is present after morphs ending in other consonant phonemes such as знакомство /zne'komstvə/ 'acquaintance'; and богатство /be'gatstvə/ 'wealth'. Also, the suffixal morph of the adjectives $\{+\mathrm{H}+\}$ is unable to appear after the suffix of the nominal stem $\{+$ ист $\}$. Instead, the morph $\{+$ ичн +$\}$ appears as illustrated by пессимистичный $/ \mathrm{p}^{\mathrm{j}} \mathrm{IS}^{\mathrm{j}} \mathrm{Im}^{\mathrm{j}} \mathrm{I}^{\mathrm{j}} \mathrm{s}^{\mathrm{j}} \mathrm{t}^{\mathrm{j}} \mathrm{it}_{\mathrm{c}} \mathrm{n}+\mathrm{j} /$ 'pessimistic'; and идеалистичный

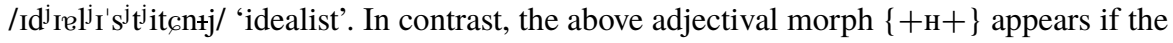
above morph $\{+$ ист $\}$ belongs to the root of the word. See examples of ненавистный

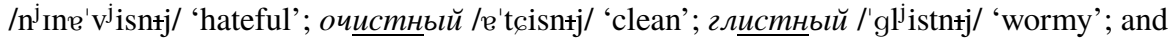
безлистный $/ \mathrm{b}^{\mathrm{j}} \mathrm{Iz} \mathrm{l}^{\mathrm{j}} \mathrm{istn}+\mathrm{j} /$ 'leafless'.

5. The distribution of morphemes in a linear arrangement creates a confusion as to whether the formation of the suffix $\{+\kappa(a)\}$ is a result of inflection or derivation. In the literature, there is a contention to assign a specific category triggered either by infection or derivation across languages. "[T] he distinction cannot be made directly in terms of the grammatical categories involved, for a category which is inflectional in one language [...] may be derivational in another" (Shopen 1985, p. 162). Thus, it becomes obvious why some scholars are tentative about generalising one case and applying it to all languages. Katamba (1993, p. 217) points out that it is hard to generalise a specific morpheme as being derivational or inflectional in all languages by saying that we "must remain sceptical" about the generalisation of both processes across languages. This caution results from the difference in syntactic rules between languages. In this sense, Katamba (1993, p. 210) claims that the diminutive morphemes are considered derivational in English, whereas the same morphemes would be considered as inflectional in some African languages.

This contention results from the difficulty of distinguishing between inflection and derivation. Although linguists have an intuitive comprehension of this distinction, the objective criteria that their intuitions rely on seem to be difficult to find and observe. Bybee (1985, p. 81) describes this distinction as "one of the most persistent undefinables in morphology". Blevins (2001, p. 218) also notes that "the status of the traditional distinction between derivation and inflection is arguably one of the most vexing questions addressed in current morphological theories". González Torres (2010, p. 105) states that the final 
morpheme $\{+\mathrm{e}\}$ in the old English word bryce 'breach' represents an overlapping case to consider it as a result of inflection or derivation; this morpheme has a simultaneous function whether derivational or inflectional.

This conundrum of ambiguous distinction leads some scholars (e.g. Lieber 1980; Di Sciullo and Williams 1987) to conclude that the conventional distinction between derivation and inflection is unilluminating and misconceived. The following problems have emerged as a result of this difficulty / contention found in the literature.

a) Controversy arises when some of the uses of the suffix $\{+\kappa(a)\}$, to create diminutiveness, feminine forms, etc., are exactly those that constitute part of inflection. This makes us regard the formation of this suffix in ambiguous terms: should it be regarded as part of derivation or inflection? Some functions of $\{+\kappa(a)\}$ seem to display inflectional properties, and yet they represent derivational morphology. The question arises here as to how someone would decide that a specific use of this suffix is derivational, while others are inflectional. Thus, we need to underline the features and the criteria that linguists require to differentiate between them.

On the one hand, the inheritance of gender as a prominent feature taken on by inflectional morphemes has been emphasised through the following concepts: 1) 'inherent character' (Katamba 1993, p. 17); 2) 'the base gender and animacy' (Hippisley 1996, pp. 201-202); and 3) 'monotonic feature' (Blevins 2001, p. 213). Subsequently, inflectional morphemes take on the same gender and class as the base word. Also, it has been argued that when inflection occurs the meaning of the base word stays the same as all various inflectional forms belong to the same paradigm or a lexeme (e.g. Carstairs-McCarthy 1987, p. 1; Feldman 1994, p. 442; Blevins 2001, p. 213).

However, some forms seem to display inflectional properties or a syntactic distribution of inflection, and yet they represent derivational morphology. This can be seen in Russian morphology when expressive derivation (affectionate, diminutive, pejorative and augmentative meaning) borrows a meaning and gender shade from the base as is usually the case for inflection. Expressive morphology is truly defined as being "transparent with respect to some morphosyntactic feature" (Stump 1993, p. 29). This transparency can be seen in the following examples: стол/'stol/ 'table' > столик/'stolj $\mathrm{Ik} /$ 'small table'; дом /'dom/ 'house' > домик /'dom' $\mathrm{Ik} /$ 'small house'; etc. Thus, Hippisley (1996, p. 221) concludes that expressive derivation in Russian resembles inflection by retaining the class of the base word; morphosyntactic features are preserved and inherited. Beard (1995, p. 93) notes that the diminutive suffixes in German and Russian take on the same gender as their base form. This can be found in квартира /kver' $\mathrm{t}^{\mathrm{j}}$ irə/ 'flat' > квартирка /kver' $\mathrm{t}$ irkə/ 'small flat'; блуза /'blusə/ 'blouse' > блузка /'bluskə/ 'small blouse', etc. Consequently, some derivational morphemes share the character of preserving the word class since expressive nouns are derived from nouns, and in turn they keep the animacy and gender of the base word.

On the other hand, other scholars have argued a changing of the word class is a dominant feature of derivational morphemes (e.g. Beard 1995, p. 99; Katamba 1993, p. 51; Blevins 2001, p. 216). This can be illustrated by варить /ve $\mathrm{r}^{\mathrm{j}} \mathrm{it}$ / 'cook' > варка /'varkə/

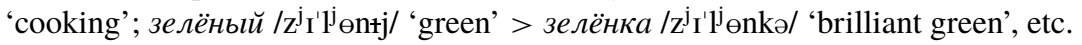

This is based on the assumption that there are two suffixes represented by the suffix $\{+\kappa(a)\}: 1)$ one keeps the same gender that denotes the diminutive meaning, which is considered to be inflectional since it shares the 'inherent character' of the gender; and 2 ) the other one serves to change the word class, so it is considered derivational.

In addition, the feature of gender changing would be equally shared between both processes: the concept of 'value switches' (Beard 1988, p. 155) assumes that deriva- 
tional morphemes change the gender of the base word. This is exemplified by студент /st ${ }^{\prime} \mathrm{d}^{\mathrm{j}} \mathrm{ent} /$ 'student (m.)' > студентка /st ${ }^{\prime} \mathrm{d}^{\mathrm{j}}$ entkə/ 'student (f.)'; активист /ekt ${ }^{\mathrm{j}} \mathrm{I}^{\mathrm{j}} \mathrm{j}^{\mathrm{i}}$ ist/ 'activist (male)' > активистка /ekt $\mathrm{I}^{\mathrm{I}} \mathrm{v}^{\mathrm{j}}$ istkə/ 'activist (female)', etc.

Regarding this, views of 'syntactically determined' (Katamba 1993, p. 47); 'obligatoriness' (Greenberg 1954, p. 207); and 'agreement' (Beard 1995, p. 99) suppose that inflectional affixes correspond to the rules imposed by syntax. It means that the syntax prescribes involuntary inflectional choices that are conditioned by the grammatical rules of a given sentence. For instance, the verb must adhere to the quantity of the subject, whether it is singular or plural, so the inflectional ending of the verb is conditioned by the quantity of the subject of the sentence. This is displayed in Fig. 5.

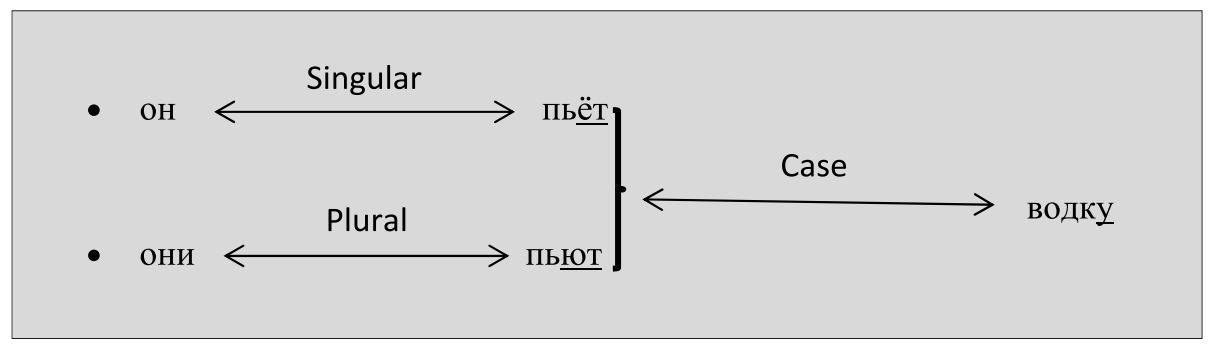

Fig. 5 Syntactic governance

The inflectional verbal ending $\{+\ddot{\mathrm{e}}\}$ is compatible with the singular subject of the sentence $\{\mathrm{oH}\} /$ 'on/ 'he', whereas in the second example, the subject $\{$ они $\} / \mathrm{en}^{\mathrm{j}} \mathrm{i} /$ 'they' is plural, so the inflectional verbal ending $\{+ю \mathrm{\}}\}$ seems different compared to the previous one. However, derivation does not require the same formula for acquiring different morphemes depending on whether the subject is singular or plural. This can be found in the above word \{водку $\} /$ 'votk / 'vodka'. Subsequently, gender changing can be reflected by inflection when the adjectival ending of ing to the type of the noun and whether it is masculine (длинныцй), feminine (длинная /'dlin:əjə/ 'long'), or neuter (Әлинное /' $\mathrm{dl}^{\mathrm{j}} \mathrm{in}$ :әjə/ 'long'). Therefore, the inflection would share the same character of derivation 'gender change'.

The disparity of functions and affiliation of the suffix $\{+\kappa(a)\}$ is shown in Fig. 6 in which it seems that some uses share more properties of derivation, while others share fewer properties associated with derivation and thus might be closer to inflection:

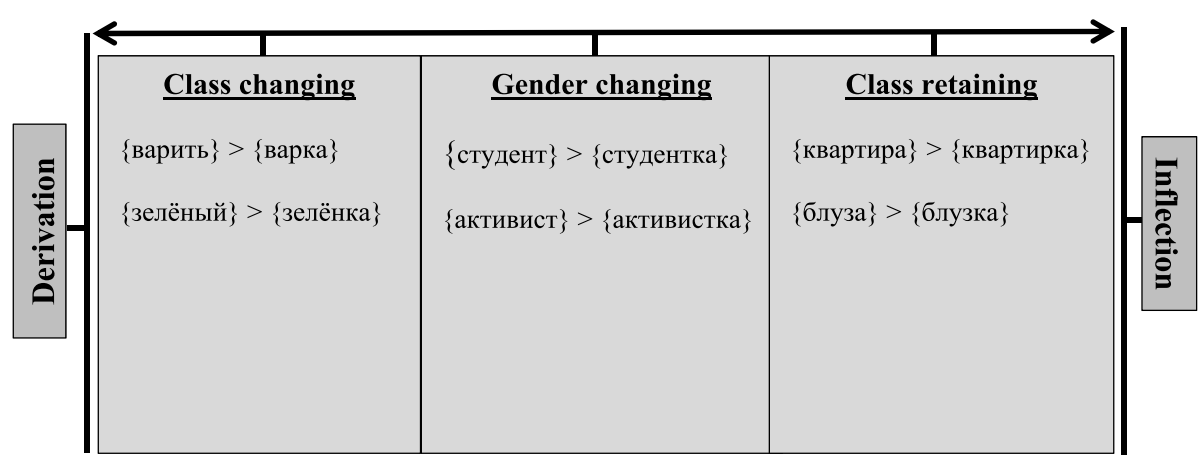

Fig. 6 Disparity of affiliation of $\{+\kappa(a)\}$ 
A significant question arises here: Is $\{+\kappa(a)\}$ actually a multitude of homonymous suffixes? This means that this suffix must be treated as various suffixes sharing the same phonological and orthographical realisation. Matthews (1974, p. 23) states that similar forms of the same word found for different applications can be expressed by the term 'homonymy'. It means that the same form can be used in different applications. In other words, homonymy results from a single form corresponding to various realisations with regards to spelling and phonology, but which delivers different grammatical senses. It is often used to describe multiple lexical and grammatical meanings. Thus, it is stated that "homonymy is one particular facet of the discrepancies between the two articulations of language" (Matthews 1974, p. 24). Carstairs-McCarthy (1987, p. 116) points out that homonymy results from having similar forms of morphosyntactic properties, so it possibly appears according to the properties thus manifested and represented. Shanskii (1968, p. 28) indicates that homonymic suffixes can be defined as morphemes that have identical forms of sound and writing, but have completely different meanings with no connection between the parent and derivative stems. Gafarova (2010, p. 128) posits that the suffix $\{+\kappa(a)\}$ represents various homonymous suffixes representing various functions.

In our data, the frequencies of the appearance of the funcions of $\{+\kappa(a)\}$ are different. Figure 7 demonstrates this contrast:

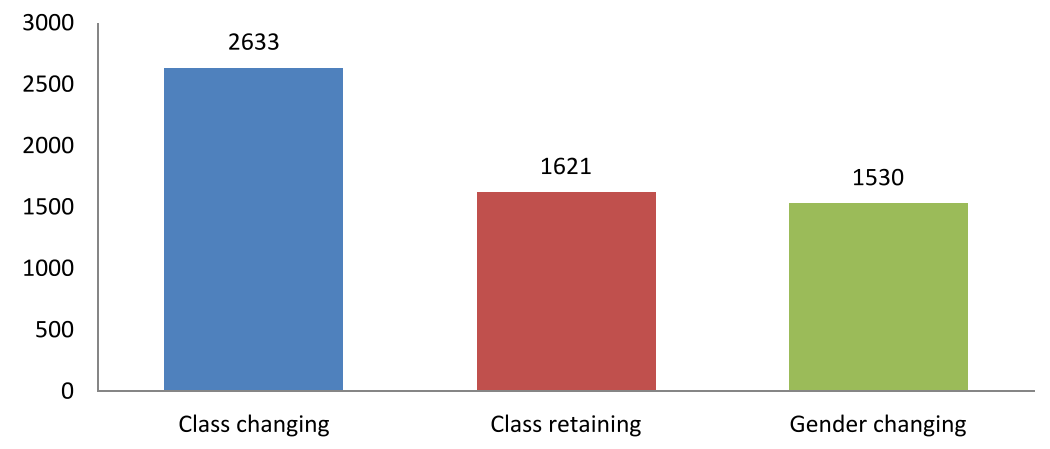

Fig. 7 Functions of $\{+\kappa(a)\}$

The semantic relationship between items is an indicator which can be used to determine whether a process is inflectional or derivational: "the greater the difference between the meaning of the derived word and the meaning of the base, the greater the likelihood that the affix is derivational" (Bybee 1985, p. 5). So Bybee proposes the concept of 'relevance' of meaning as part of the 'Network Morphology' account. This concept implies that the meaning of the second word results from the meaning of the first one, so the former is triggered by the latter in its formation.

Similarly, Feldman (1994, p. 442) posits that inflection tends to take on a compositionality of meaning somewhere between the inflected form and its base word, whereas for derivation this is less often the case. Miceli and Caramazza (1988, p. 25) point out that word meaning may be subject to alteration by derivation but never by inflection. This can be seen in the following example: brother > brotherhood. Accordingly, the contrast of 'meaningful relevance' will decide whether new formations are inflectional or derivational. A given process is inflectional if there is a strong relevance of meaning between the formative elements. Otherwise, the process will be interpreted as derivational.

In order to examine the arguments pertaining to semantic relevance discussed above, we have created the following specific terms 'MATCH', 'DIVERGE', and 'MODIFY'. These terms are defined as follows: 
1. 'MATCH' refers to those words which reflect a similar meaning to that of their base words. In these formations, the referent indicates coreferential meaning as illustrated by оперетта > оперетка. Also, the words may obtain a symmetrical meaning com-

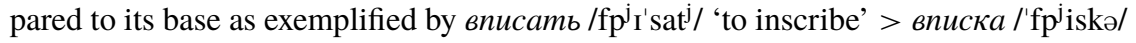
'inscribing'.

2. 'DIVERGE' represents those words whose meaning does not match that of their bases as in $в о \partial а / \mathrm{ve}$ 'da/ 'water' > водка /'votkə/ 'vodka'. The referent indicates a different meaning compared to its base, therefore, водка 'vodka' refers to a different item than вода 'water'.

3. 'MODIFY' indicates those words which slightly modify their base meaning either by

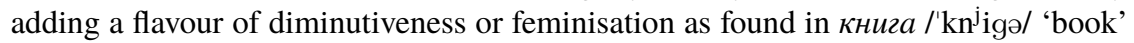
$>$ книжка /'knjiskz/ 'small book'; and болгарин > болгарка. The referent indicates an asymmetrical meaning when, for example, болгарин can be used to refer to both genders but болгарка can only be used to refer to the female gender. Similarly, the word книга can also refer to both книга and книжка. However, книжка cannot be used to refer to книга which seems bigger in terms of size. Subsequently, the referent in this term imposes that the meaning of the surface word cannot be used to refer to the exact meaning of its base since it has been slightly modified. The distribution of the above terms in our data is shown in Fig. 8.

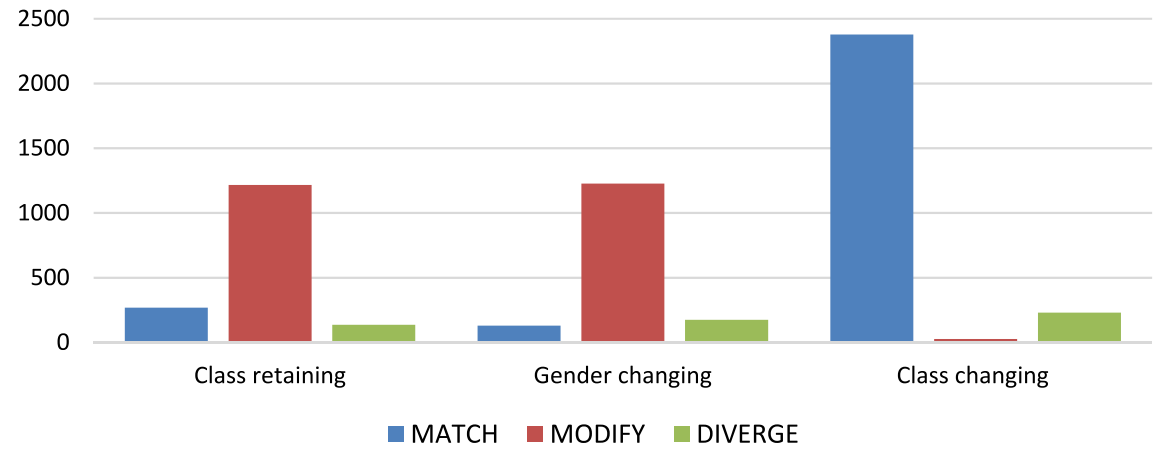

Fig. 8 Semantic relevance of $\{+\kappa(a)\}$

The above distribution of these terms indicates that a change of meaning is reflected in all above functions of the suffix $\{+\kappa(a)\}$. This possibly refutes the assumption that it has multiple homonymous suffixes: one derivational and the other one inflectional. The reason is that inflectional morphemes must preserve the same meaning as their base. This means then that some functions of this suffix, in particular 'class retaining' and 'gender changing', cannot be regarded as being closer to inflection as presented in Fig. 6.

b) The alternative option is to consider this suffix as simply just one derivational suffix with different morphological functions. This gives a plausible explanation for the multiplicity of $\{+\kappa(\mathrm{a})\}$ functions.

Accordingly, the multiple functions of this suffix lead us to treat it as a polyfunctional one. The phonological realisation would be identical for both, but the diminutive meaning differs from the feminine meaning. Dement'ev (1959, pp. 9-10) points out that the language consists of a complex system in which phenomena are related or conditioned to each other. Therefore, a suffix like $\{+$ щиц $\}$ or $\{+$ чица $\}$ may denote a specific function 
(carried out by a female), while another suffix may take on multiple functions, such as the suffix $\{+\kappa(\mathrm{a})\}$ referring to the diminutive meaning, as illustrated by ropa /ge'ra/ 'mountain' > горка /'gorkə/ 'hill'; and the feminine equivalent to the masculine form, such as

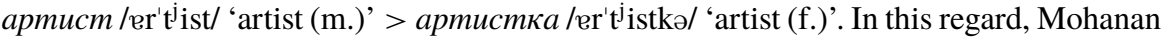
$(1985$, p. 9) posits that the suffix $\{+\kappa(\mathrm{a})\}$ has to be a representative of a feminine feature (agentive feminiser) and a diminutive one respectively. Hence, the assumption that one derivational polyfunctional suffix exists provides a solid reason as to why the same suffix exposes different morphological functions / meanings.

This assumption is based on the distinct features of this suffix. One of these features is the formation of new derivative words (Carstairs-McCarthy 2002, p. 30). Subsequently, these words might modify their class or might shift their meaning compared to the base word whether to express diminutiveness or alter gender, bearing in mind that the word category is not necessarily susceptible to change. Thus, words with the suffix $\{+\kappa(a)\}$ would be considered derivational when denoting the following functions: a) The first one is considered grammatical (changing the word class), as illustrated by варить > варка; and зелёный > зелёнка; and b) the second one is considered semantic and expresses the feminine gender, thereby changing the gender as exemplified by студент > студентка; and активист > активистка. It also expresses a diminutive meaning, thereby inheriting the gender as shown by квартира $>$ квартирка; and блуза $>$ блузка.

This organisation of morpheme functions has gained support from Stump (2016, p. 229) through emphasising the concept 'polyfunctionality'- "the systematic use of the same morphology for more than one purpose". Its framework links the multiple manifestations of a certain category if they are identically marked in terms of phonetics, morphology and lexicon. Therefore, this concept organises the multiplicity of meanings / functions (e.g. the agentive feminiser and the diminutive constituent) of the suffix $\{+\kappa(a)\}$ by treating them as polyfunctional forms for the same category. This organisation shows that there is a single category and multiple forms classified by the frame of polyfunctions to the main one. This organisation is conditioned by the similarity of phonetic, morphological and lexical properties present between its members. One form links to other subcategories with distinction only in function between them. This polyfunctional organisation of the suffix $\{+\kappa(a)\}$ is presented in Fig. 9.

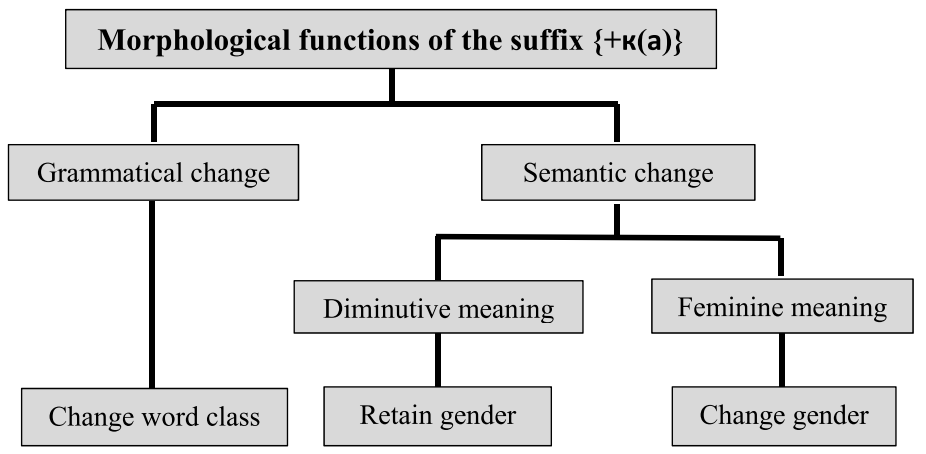

Fig. 9 Morphological functions of $\{+\kappa(a)\}$

However, one could ask why we are obliged to treat this suffix as derivational with multiple sub-functions. Instead, one can argue that $\{+\kappa(a)\}$ is not one but multiple homonymous suffixes delivering discrete meanings / functions. 
In this sense, we have observed that surface words formed by $\{+\kappa(\mathrm{a})\}$ are influenced by their base in terms of the meanings / functions they can deliver. Accordingly, homonymity is reflected by having discrete suffixes in terms of function; each function is associated with a certain type of base word, especially class. Figure 10 represents the distribution of meanings / functions of $\{+\kappa(a)\}$ based on the word class of the base:

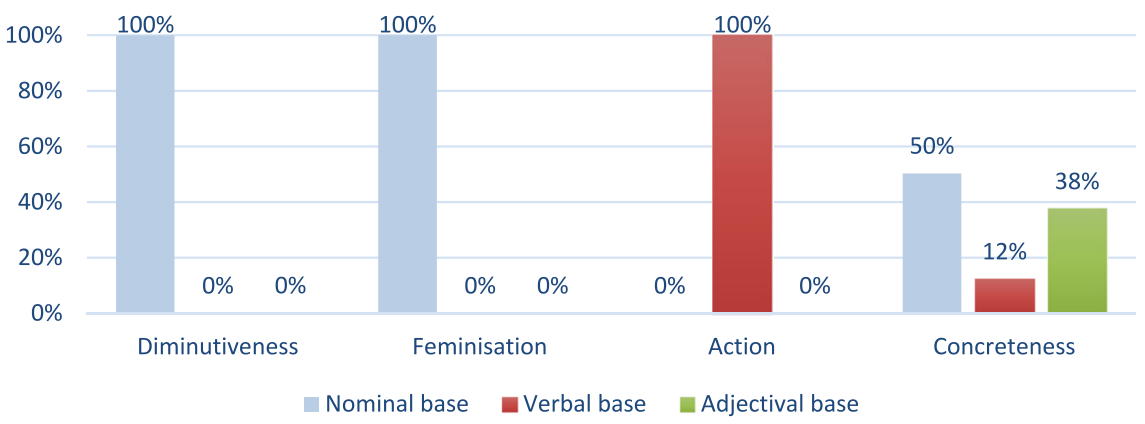

Fig. 10 Influence of word class

Figure 10 shows the percentage of meanings expressed by the suffix $\{+\kappa(a)\}$. Denominal words mainly serve to indicate a diminutive meaning (блоха /ble'xa/ 'flea' > блои $\kappa a$ /'bloskə/ 'small flea') and alter the gender (agentive feminiser) as well (блондин /blen'din/ 'man with blonde hair' > блондинка /blen' dinkə/ 'woman with blonde hair'), whereas the remaining proportion which is marked by the label 'other', indicate either a diverted meaning (вода/ve'da/ 'water' > водка /'votkə/ 'vodka'; and $\partial p y z /$ 'druk/ 'friend' $>$ дружка /'druşkə/ 'bridesman, groomsman') or a symetrical meaning in comparison to that of the base (оперетта > оперетка; and галерея /gәl $\mathrm{l}^{\mathrm{j}} \mathrm{r}^{\mathrm{j}} \mathrm{ej}$ e/ 'gallery' > галёр$\kappa a / g e^{\prime} \mathrm{l}^{\mathrm{j}} \ominus \mathrm{k} \mathrm{k} /$ ' 'gallery'). Deverbal words primarily express an action meaning (вписать

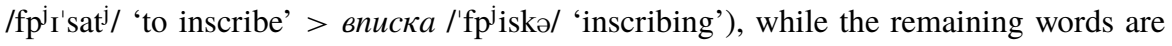
divided into the following: 1) words which indicate a semantically divergent meaning with little overlap (жировать /ztre'vat'/ 'to grease' > жировка /z̨t'rofkə/ 'rent bill';

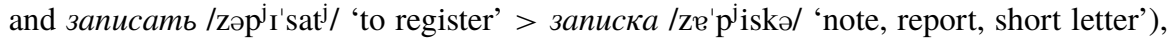
and 2) words that express a certain feature which indictaes the character of animate or unanimate beings (знать /'znat'/ 'to know' > знайка /'znajkə/ 'knowledgeable person'; and недоуииться $/ \mathrm{n}^{\mathrm{j}}$ Idəə' 't educated person'). Deadjectival words virtually denote characteristics of something in association with their base (дешёвый /d $\mathrm{I}^{\mathrm{j}}$ 'şovtj/ 'cheap' > дешёвка / $\mathrm{d}^{\mathrm{j}} \mathrm{I}$ 'şofkə/ 'cheapness, cheap rubbish'; and осторожный > осторожка), but the remaining ones express a heterogeneity of meaning between the base and surface word (весёльй $/ \mathrm{v}^{\mathrm{j}}{ }_{1}{ }^{\mathrm{j}} \mathrm{s}_{\ominus l \mathrm{jj}}$ / 'cheerful'

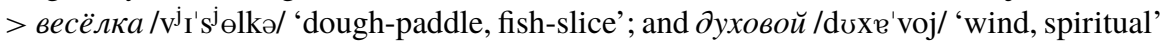
$>$ духовка /dv'xofkə/ 'oven').

It becomes clear that a certain base would be used to deliver a certain meaning / function, thereby utilising multiple homonymous suffixes of $\{+\kappa(a)\}$. In other words, a nominal base is mainly used to express diminutiveness and feminisation. A verbal basis primarily serves to create the action meaning though. Meanwhile, adjectival base almost always contributes to form words indicating the specific characteristics of certain things. This dichotomy of bases results from the diversity of meanings / functions delivered by the above suffix.

Interestingly, this taxonomic homonymous view is supported by multiple scholars; Vinogradov, Istrina, and Barxudarov (1952, pp. 233-234) point out that words with 
$\{+\kappa(a)\}$ denoting the feminine meaning are only derived from a nominal base such as

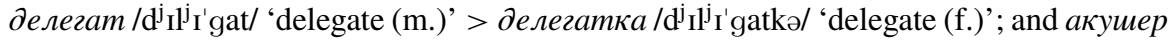

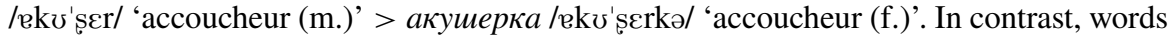
expressing certain characteristics with respect to size, measurement, material, and designation are possibly derived from the adjectival stem of $\{+$ ов / ев +$\}$. Namely, дюймовый /d $\mathrm{dj}^{\mathrm{j}}$ 'movij/ 'one-inch (long/wide)' > дюймовка /d $\mathrm{dj}^{\mathrm{j}}$ 'mofkə/ 'one-inch board / plank'; метровый / $\mathrm{m}^{\mathrm{j}} \mathrm{It}$ 'rovij/ 'meter' > метровка / $\mathrm{m}^{\mathrm{j}} \mathrm{It}$ 'rofkə/ 'one meter (length / extent)'; абрикосовый /ebr ${ }_{\mathrm{I}}^{\mathrm{j}}$ 'kosəv+j/ 'apricot' > абрикосовка /ebr $\mathrm{r}_{\mathrm{I}} \mathrm{I}^{\prime} \mathrm{kos} ə \mathrm{fkə/}$ / 'apricot liqueur'; виш-

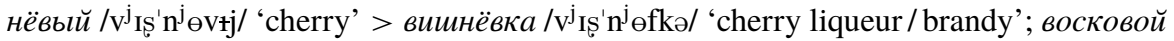
/vəske'voj/ 'waxy' > восковка /ves'kofkə/ 'wax-paper'; and врубовый /'vrubəvıj/ 'cutting' > врубовка /'vrubəfkə/ 'cutter'.

Meanwhile, verbal stems ending in $\{+$ овать $\}$ and similar endings result in the formation of words expressing an action meaning. Similarly, Townsend (1975, p. 22) notes that "the nominal suffix -|к- makes nouns of action|result from verbs (выставить - display, выстав|ка - display(ing), exhibit(ion)". Also, Uluxanov (1975, p. 42) points out that verbal stems of $\{+$ овать $\}$ and $\{+$ ировать $\}$ give rise to the formation of nouns in which the suffix $\{+\kappa(a)\}$ indicates an action meaning; their verbal base usually motivate the above meaning: "The causative meaning is highly relevant to verbs, since it affects quite directly the event or state being described by the verb stem" (Bybee 1985, pp. 17-18).

To oppose the above view of homonymity, the concept of 'cognitive semantics' proposed first by Lakoff (1987, p. 17) and developed later by Janda (1993, p. 6) suggests that there is one main prototypical member and other less prototypical members that are affiliated to the main one by their interrelationship. Hence, this concept contradicts the existence of multiple homonymous suffixes of $\{+\kappa(a)\}$. This concept assumes a radial distribution of functions, rather than a hierarchical one. There is a prototype with its schema, and the relationship between the prototype and other schemas is determined by the closeness of fit between them: a small change in schema will be perceived as a close relationship, whereas multiple changes in the schema create a more distant relationship.

c) Another problem appears when we look at Fig. 5 (see above). This figure has shown that the inflectional ending $\{+\mathrm{a}\}$ is governed by the accusative case of the transitive verb of the sentence, as illustrated by водку. Hence, the question arises here: is the suffix $\{+\kappa(a)\}$ composed of one element? If yes, then why is it affected by the syntax despite the fact that is has been argued that its formation is a result of a derivational process. The scope of derivation is detached from the effect of syntactic rules as it is related to word structure and engages with word components. Thus, presuming the above suffix consists of one element seems irrelevant to the morphological properties of either derivation or inflection. If we assume that its formation is only triggered by inflection, this poses a contradiction, especially with regards to the formation of new words, which is the main feature of the derivation process. At the same time, if it is claimed that its formation results only from derivation, so any word with the above suffix would not be affected by syntactic rules and this is not the case observed earlier in Fig. 5. Subsequently, this leads us to argue that the composition of the above suffix involves two elements: the suffix $\{+\kappa+\}$ and the ending $\{+\mathrm{a}\}$. This segmentation provides a plausible interpretation for both derivational and inflectional processes that occur in association with forming this suffix. First, it links the concept of forming new words with the derivational constituent $\{+\kappa+\}$ which gives rise to the production of new words, so it represents the essence of the derivational process. Second, it offers a relevant explanation about the commitment of the inflectional morphemes to the syntax via taking the inflectional constituent $\{+a\}$ as an ending that is subject to syntactic rules into consideration, as we have seen earlier in Fig. 5. 
Subtractive morphology can influence some formations. This causes a formal modification to surface words which the IP model seems to explain better (e.g. Matthews 1974; Anderson 1992). Regarding this, Anderson (1992, p. 187) points out that surface words may not correspond to the full existing form of their base. This can be seen in demonstrate $>$ demonstrable; navigate $>$ navigable; formulate $>$ formulable, etc. in which the morpheme $\{+$ ate $\}$ is truncated as a result of the generation of new words. Thus, Anderson suggests the following rule shown in Fig. 11 which describes the deletion of $\{+$ ate $\}$ and the addition of $\{+$ able $\}$.

(3) $[\operatorname{Adj}[v X+A T E]+A B L E] \longrightarrow[\operatorname{Adj}[v X+\varnothing]+A B L E]$

Fig. 11 Anderson's truncation rule: Adapted from Anderson (1992, p. 187)

Subsequently, the IP model is based on the assumption of rules which describe the word formation process. However, this leads to the emergence of specific constraints and problems which are presented below.

1. It is unclear whether the rule shown in Fig. 11 operates on all constituents of the word including endings, or if it just operates on the word stem. In other words, does the formation of вода /ve'da/ 'water' > водка /'votkə/ 'vodka' expose a rule that leads to the truncation of the inflectional ending $\{+\mathrm{a}\}$, coinciding with the attachment of the suffix $\{+\kappa(a)\}$ ? It is customary that word formation rules (WFRs) operate around the stem boundary, so the above formation (вода > водка) possibly occurs as a result of additive morphology which does not impose any truncation; the inflectional ending $\{+a\}$ is transferred to the similar form which already exists in the composition of the suffix $\{+\kappa(a)\}$. This model thus assumes that WFRs usually operate around the stem boundary as exemplified by болгарин > болгарка; бедняк > беднячка; деревня > деревенька, etc.; this is shown in Fig. 12.

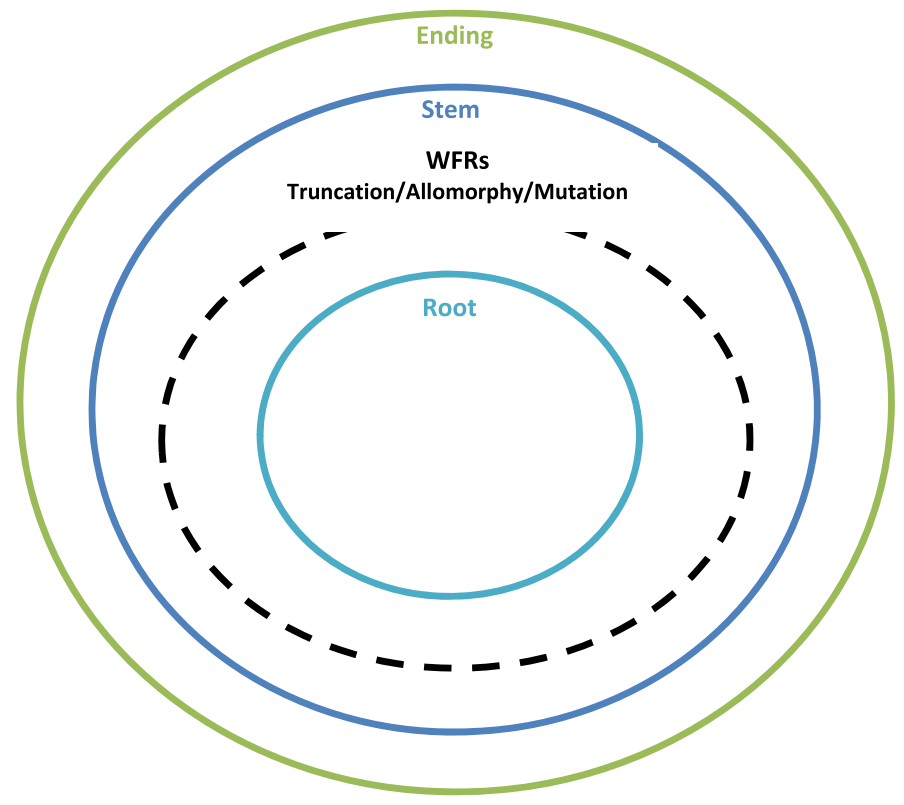

Fig. 12 Operation of WFRs 
However, controversy arises when other formations in which WFRs operate around the root boundary are found as in заяи /'zajıts/ 'hare' > зайка /'zajkə/ 'lovely hare'; игла /Ig'la/ 'needle' > иголка /'Igolkə/ 'needle'; мьтьь /'mit'/ 'to wash' > мойка /'mojkə/ 'washing'; рука > руика; аптека /ер't $\mathrm{t} \mathrm{ekə/}$ 'pharmacy' > аптечка /ер't'etckə/ 'first aid kit', etc. To explain this, we might say that the IP model assumes the existence of a rule that organises the operation of WFRs around the word stem. In contrast, when the root is influenced by these rules, these formations are possibly explained as exceptions to the above rule. To some extent, this explanation resembles the theoretical concept of the 'dual-route account' when there are regularities and irregularities. However, the attempt to justify these exceptions of the 'dual-route account' seems invalid since the IP model is typically associated with generative models in which morphology is just a feature of word-formation or syntax. The IP model allows us to take the entire word into account when constructing forms because they are not interpreted as being 'linear'. However, the dual-route account tends to be close to the morpheme-based approach since it assumes a decomposition of word elements. Consequently, these exceptions may represent a problem which would need to be explained by the IP model.

2. On the one hand, we have noticed that when a word ends in a combination of a vowel and a consonant (VC) or a consonant and a vowel (CV), then it is more likely to avoid any type of truncation or alteration to form new words as illustrated by акробаm /ekre'bat/ 'acrobat (m.)' > акробатка /ekre'batkə/ 'acrobat (f.)'; богач /be'gatc/ 'rich man' > богачка /be'gatckə/ 'rich woman'; амnула /'amp»lə/ 'ampoule' > ампулка 'small ampoule', etc. However, some formations ending in these combinations are subjected to mutation or

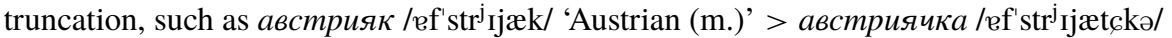
'Austrian (f.)'; луковииа /'lukәv Itsə/ 'onion' > луковка /'lukəfkə/ 'small onion'; болгарин > болгарка; колонна /ke'lon:ə/ 'column' > колонка /ke'lonkə/ 'small column'; onеретта /ер $\mathrm{p}^{\mathrm{j}} \mathrm{r}^{\mathrm{j}} \mathrm{etə} /$ 'operetta' > оперетка / $\mathrm{ep}^{\mathrm{j}} \mathrm{I}^{\mathrm{r}} \mathrm{r}^{\mathrm{j}}$ etkə/ 'operetta', etc. Moreover, other formations are subjected to truncation and alteration when the (jot) precedes the suffix $\{+\kappa(a)\}$, coinciding with truncating specific morphemes as shown by кроить $/ \mathrm{kre}^{\prime} \mathrm{it}^{\mathrm{j}} /$ 'to cut out' > кройка /'krojkə/ 'cutting-out'; напаять /nəpe'jæt'/ 'to solder' > напайка /ne'pajkə/ 'soldering on'; хозяин /хе' z'æin/ 'landlord, owner (m.)' > хозяйка /хе' $z^{\mathrm{j}} æ j \mathrm{jkə/}$ 'landlord, owner (f.)', etc.

On the other hand, words ending in a combination of (CC/ VV) are possibly subject to alteration or truncation. Namely, семья $/ \mathrm{s}^{\mathrm{j}} \mathrm{I}^{\prime} \mathrm{m}^{\mathrm{j}} \mathrm{j} /$ ' 'family' > семейка $/ \mathrm{s}^{\mathrm{j}} \mathrm{I}^{\prime} \mathrm{m}^{\mathrm{j}} \mathrm{ejkə/}$ 'small

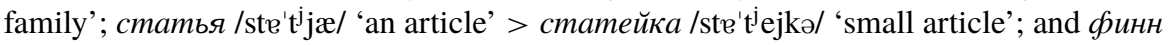
/'fin:/ 'Finnish man' > финка /'f'inkə/ 'Finnish woman'. Conversely, other formations ending in this combination are not affected by alteration or truncation. See examples of богатей /bəge't'jej/ 'rich man' > богатейка /bəge't'ejkə/ 'rich woman'; and интеллигент $/ \mathrm{In}^{\mathrm{j}} \mathrm{t}_{\mathrm{I}} \mathrm{I}^{\mathrm{j}} \mathrm{I}^{\prime} g^{\mathrm{j}}$ ent/ 'intellectual man' > интеллигентка $/ \mathrm{In}^{\mathrm{j}} \mathrm{t}^{\mathrm{j}} \mathrm{l}^{\mathrm{j}} \mathrm{I}^{\prime} g^{\mathrm{j}}$ entkə/ 'intellectual woman'. Consequently, the IP model is unable to generalise a static rule which organises truncating or alternating specific words on the basis of types of phonemes.

3. The IP model assumes that most deverbal formations involve a truncation of the verbal suffix. As illustrated by вмазать /'vmazət'/ 'to fix in' > вмазка /'vmaskə/ 'fixing'; and возить /ve'z' $\mathrm{z}_{\mathrm{j}}^{\mathrm{j}}$ / 'to drive, carry' > возка /'voskə/ 'carriage'. However, other formations are formed by using the stem of the present tense as a result of allomorphy. This can be shown by класть /'klas jtj/ 'to lay down / on' (кладу /kle'du/) > кладка /'klatkə/ 'laying';

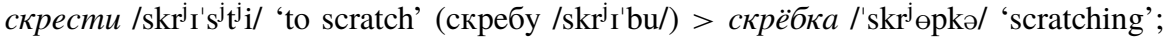

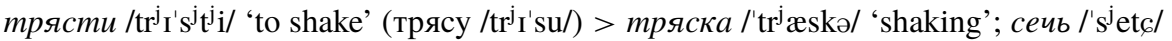

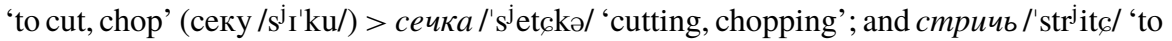
trim, clip' (стригу /str' ${ }^{\mathrm{j}}{ }^{\prime} g \mathrm{u} /$ ) > стрижка /'str ${ }^{\mathrm{j}} \mathrm{j}_{\text {șkə/ }}$ 'trimming, clipping'. Thus, multiple 
rules are posited by the IP model to explain the variety of formations within the same base. This adds a complexity to words formed by the suffix $\{+\kappa(a)\}$.

4. Allomorphy is presented in various forms while forming words with the suffix $\{+\kappa(a)\}$. This phonetic alteration possibly occurs between the following phonemes:

1) $/ \varnothing /-/ \mathrm{e} /, / \mathrm{ë} /$ :

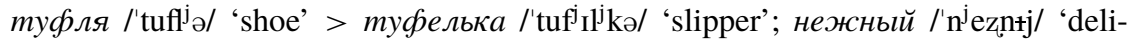
cate' > неженка /'n 'nętnkə/ 'sensitive person'; копна /kep'na/ 'shock' > копёнка

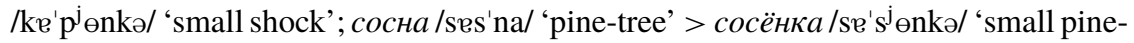
tree'; and драть /'drat'/ 'to tear, strip off' > дёрка /' $\mathrm{d}^{\mathrm{j}} \ominus \mathrm{erkə/}$ 'tearing, stripping off'.

2) $/ \varnothing /-/ \mathrm{o} / \mathrm{:}$

кухня /'kuхn $\mathrm{j}_{\text {ə/ }}$ 'kitchen' > кухонка /'kuхеnkə/ 'kitchenette'; выбрать /'vibrət'/ 'to pick, select' > выєборка /'vibərkə/ 'selection'; and убрать / b' rat' / 'to remove, harvest, tidy' > уборка / $v$ 'borkə/ 'removal, harvesting, tidying'.

3) $/ \varnothing /-/ ы /:$

послать /pe'slatj/ 'to send' > посылка /pe'silkə/ 'sending, parcel, errand'; and nрислать $/ \mathrm{pr}^{\mathrm{j}} \mathrm{I}^{\prime}$ slat $^{\mathrm{j} /}$ ' to send, dispatch' > присылка $/ \mathrm{pr}^{\mathrm{j}} \mathrm{I}^{\prime}$ silkə/ 'sending, dispatching'.

4) $/ \mathrm{e} / \mathrm{l}-\mathrm{ë} /$ :

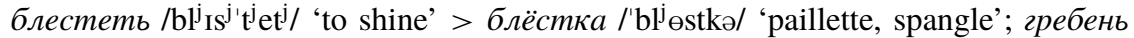

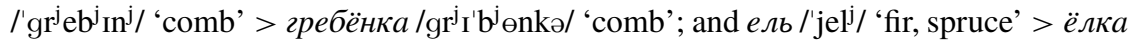
/'jelkə/ 'fir (-tree)'.

5) $/ \mathrm{e} / \mathrm{lo} /$ :

ториевать /tərtst'vat'/ 'to pave with wood blocks' > ториовка /ter'tsofkə/ 'wood pavement'.

6) $/ \breve{\mathrm{h}} /-/ \ddot{\mathrm{e}} /$ :

окаймить /еkеj'm'jitj/ 'to fringe' > окаёмка /eke'jømkə/ 'surrounding something'.

7) $/ \mathrm{a} /-/ \mathrm{o} /$ :

ладья /le' $\mathrm{d}_{\mathrm{j}}^{\mathrm{j} æ /}$ 'boat' > лодка /'lotkə/ 'small boat'.

8) /ним/ - /ем/, /ём/, /им/:

вынимать /vtn $\mathrm{I}^{\mathrm{j}}$ 'mat $/$ 'to take out' > выемка /'vijımkə/ 'taking out'; снимать /sn's'mat'/ 'to photograph' > съёмка /'sjөmkə/ 'photographing'; and поднимать /pədn ${ }^{\mathrm{j}} \mathrm{I}^{\prime} \mathrm{mat}$ / / 'to lift/raise' > подъёмка /pedj'өmkə/ 'lifting'; and перенимать $/ \mathrm{p}^{\mathrm{j}} \mathrm{Ir}^{\mathrm{j}} \mathrm{In}^{\mathrm{j}} \mathrm{I}^{\prime}$ mat $\mathrm{t}^{\mathrm{j}}$ ' 'to take over' > переимка $/ \mathrm{p}^{\mathrm{j}} \mathrm{Ir}^{\mathrm{j}}{ }^{\mathrm{j}}$ 'imkə/ 'taking over'.

Thus, the IP model implies a sporadic distribution of multiple allomorphs of various formations. This means that some words obtain specific allomorphs and yet others are different.

5. The IP model presupposes that there is more than one potential rule to interpret a certain formation. For instance, presumably, the WFRs for нежный > неженка is possibly explained by having an allomorphy which affects the stem, coinciding with the addition of the suffix $\{+\kappa(a)\}$. A second possibility is that the adjectival suffix $\{+$ ный $\}$ is truncated first, and then the compound suffix $\{+$ енк $(\mathrm{a})\}$ is attached. This overlapping situation between the processes of (allomorphy+additive morphology) versus (truncation+compound suffixation) can also be found in other formations. Consequently, multiple interpretations that contradict each other can be posited to explain the same formation. This causes ambiguity when explaining a certain formation with a certain rule. This mostly results from the fact that this sort of taxonomic approach to morphological processes ends up being far too powerful; we have to posit too many potential processes that are then unconstrained, and we end up with no satisfactory explanation / rule at all as a result. 
Unlike the above models, the WP would solve the problems discussed earlier, thereby relying on the storage-based model which is valid for all formations. Langacker (2002, p. 17) introduces a pattern under the term 'structural description'. This term assumes that the relationship between related words can be described by a stored pattern. To exemplify this, the stored pattern imposed for нежный > неженка is the following: [X] - [Хка]. The formation process, therefore, is not explained at a morpheme level, but on the word level.

Thus, the above pattern can exhibit semantic and phonological correlation without any problems when its correspondence is infringed whether semantically or phonologically. Thus, both units, the base and surface word, are paradigmatically related to each other, so this represents the essence of the whole-word approach. Moreover, this pattern appears to work nicely in conjuction with the concept of 'analogy' when the intention is the creation of new forms; it can also be used as a model to create new words by imitating the formation of the most frequent form in memory. This suggests that what is at work here is analogy rather than rule-based word-formation. Consequently, an analogical account will work much better than a rule-based one at explaining the variety of relationships that exist between the surface form and the base form.

\subsection{Approaches that can be rejected as a result of the analysis of $\{+\kappa(a)\}$ formations}

The implication of the relevance between related words with $\{+\kappa(a)\}$ would contradict some perspectives proposed by some scholars. It has been indicated in Sect. 4.2 that the semantic relevance between items can determine whether a process is inflectional or derivational (e.g. Bybee 1985, p. 5; Miceli and Caramazza 1988, p. 25; Feldman 1994, p. 442). A strong semantic relevance between items is considered inflectional, whereas weak and divergent semantic relevance is considered derivational.

However, it has been found that words containing the derivational suffix $\{+\kappa(a)\}$ have greater semantic relevance. In Sect. 4.2 we have introduced the terms 'MATCH', 'DIVERGE', and 'MODIFY' in order to examine the level of relevance found in these formations. Subsequently, the distribution of the above terms in formations of $\{+\kappa(a)\}$ is shown in Fig. 13.

Fig. 13 The distribution of semantic relevance

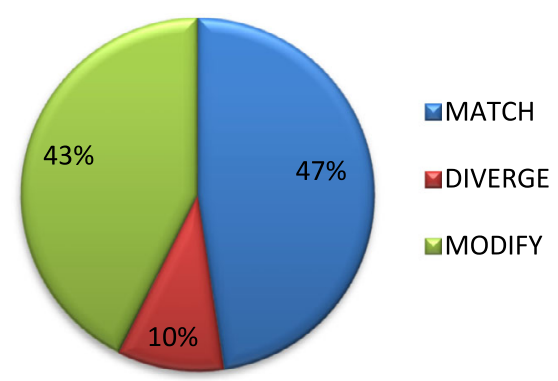

Apparently, the heterogeneity of meaning represents the smallest number. This heterogeneity varies according to the type of base word. The following chart of semantic disparity (Fig. 14) represents the differences found between bases with respect to semantic correspondence: 


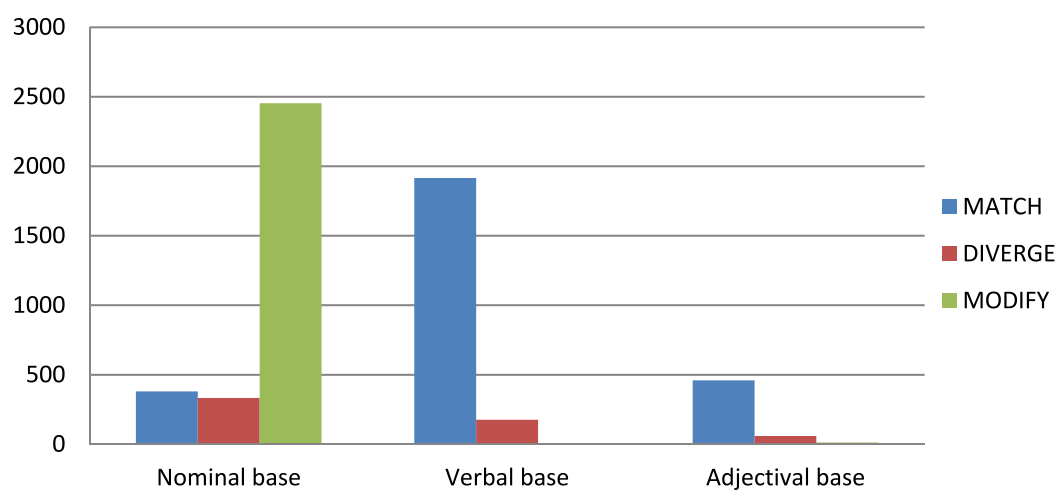

Fig. 14 The disparity of semantic relevance

As a result, semantic relevance is primarily expressed by the majority of words with $\{+\kappa(a)\}$ as shown in Fig. 13 and Fig. 14. Even though the term 'MODIFY' refers to a modified meaning, it still reflects a correlation between meaning and base. Thus, we might argue that derivational morphology presented by formations of $\{+\kappa(a)\}$ also reflects high semantic relevance. This possibly contradicts the above views that only inflection can result in the feature of high semantic relevance.

In the literature, derivational morphology is described as being unpredictable. This view is triggered by the addressing of the concepts 'productivity' and 'generality', to distinguish between inflection and derivation. The common assumption in theoretical morphology (e.g. Bauer 1988, p. 15; Feldman 1994, p. 442; Stump 1998, p. 16; Booij 2000, p. 363; Koefoed and van Marle 2000, p. 303; Haspelmath 2002, p. 71; Gaeta 2007, p. 182) is that inflectional productivity is generally higher than derivational: "inflection is generally more productive than derivation" (Stump 1998, p. 16); "inflectional formations are more productive [...] than are derivational formations" (Feldman 1994, p. 442). Inflection seems to be more predictable than derivation. Other scholars (e.g. Bybee 1985, p. 5; Katamba 1993, p. 207; Blevins 2001, p. 213) point out that inflectional forms tend to be generated automatically and regularly depending on their environment. Conversely, the derivational process may behave sporadically owing to the lack of regular morphemes for the same application; therefore, their behaviour is unpredictable.

'Unpredictability' is a negative feature: it describes what cannot be done or what is difficult to do, and it does not reflect what speakers do. However, speakers have almost no difficulty in deciding which suffix to add or what it means. Our data has shown that we can predict safely for any particular noun how it will implement diminutiveness, feminisation, etc., and we can always predict what function(s) the suffix $\{+\kappa(\mathrm{a})\}$ will have as shown by Fig. 10. So we have a mismatch in that 'theory' suggests something is difficult and disparate, and yet we know that most of the time speakers consistently agree on the suffix needed for a particular function and interpret it consistently when they hear or see it.

Accordingly, our suffix has shown the ability to be predictable in its environment. This predictability is possibly triggered by a speaker's use of the suffix in certain applications. This use is perhaps associated with the concept of 'expressive derivation'. Hippisley (1996, pp. 201-202) notes that expressive derivation in Russian (e.g. affectionate, diminutive, pejorative and augmentative meaning) usually borrows the ground meaning of its base. As exemplified by стол/'stol/ 'table' > столик /'stolj Ik/ 'small table'; and бол /'dom/ 'house' $>$ домик /'dom' $\mathrm{Ik} /$ 'small house'. Also, Beard (1988, p. 163) points out that the subjec- 
tive expressivity of the speaker is manifested when s/he utilises specific affixes to express different meanings of human emotions. In other words, the attitude of the speaker towards the merit of the referent is interpreted by using, for instance, the derivative suffix $\{+\kappa(a)\}$ to refer to the affectional meaning as exemplified by $\partial я \partial я /{ }^{\prime} \mathrm{d}^{\mathrm{j}} \mathrm{d}^{\mathrm{j}} \partial /$ 'uncle' $>\partial я \partial ь \kappa a$ I' $\mathrm{d}^{\mathrm{j}} \mathrm{t}^{\mathrm{j}} \mathrm{kə} /$ 'uncle' (affectionate); тётя /' $\mathrm{t}^{\mathrm{j}} \mathrm{e}^{\mathrm{j}} \mathrm{\partial} /$ 'aunt' > тётка /' $\mathrm{t}^{\mathrm{j}} \mathrm{\theta tkə} \mathrm{k} /$ 'aunt' (affectionate), etc.

Conversely, the suffix $\{+\kappa(\mathrm{a})\}$ can also be used to express pejorative meaning as found in идея /I' $\mathrm{d}^{\mathrm{j}} \mathrm{ejə} /$ 'idea/notion' > идейка /I'd $\mathrm{j}$ ejkə/ 'sort of idea'; мужиина /mひ'с:inə/ 'man' $>$ мужиинка /mひ'c:inkə/ 'sort of man', etc. Therefore, expressive derivation seems to be "transparent with respect to some morphosyntactic feature[s]" (Stump 1993, p. 29). Hence, derivation may retain the animacy of the base; morphosyntactic features can be preserved by expressive derivational affixes. This is possibly reflected by an inheritance of meaning and gender as well (стол > столик; дом > домик; дядя > дядька; and идея > идей$\kappa a)$. This may result from the effect of the 'Network Morphology' account: the meaning of the derivative word is affected by the meaning of its base 'most of time'. This means that the semantic meaning of the surface word is complementary to the meaning of its base. It means that the meaning of the surface word corresponds to the meaning of its base lexeme.

\subsection{A comparison based on the analysis of $\{+\kappa(a)\}$ formations}

According to the word-based approach, the morpheme $\{+\kappa(a)\}$ has contributed to the formation of different categories which are shown in Fig. 1. This might be considered a problem for some morphological models since these categories cannot be recognised by them. The difference in the approach towards these categories is shown in Table 4, in which the term 'frequency' indicates the representation of each category.

Table 4 Comparative view towards different categories of $\{+\kappa(a)\}$

\begin{tabular}{llll}
\hline & The suffix $\{+\mathrm{K}(\mathrm{a})\}$ & Compound suffixes & $\{+\mathrm{K}(\mathrm{a})\}$ as a part of the root \\
\hline WP & $\sqrt{ }$ & $\sqrt{ }$ & $\sqrt{ }$ \\
IP & $\sqrt{ }$ & $\sqrt{ }$ & $\sqrt{ }$ \\
IA & $\sqrt{ }$ & $?$ & $?$ \\
Frequency & 0.79 & 0.20 & 0.01 \\
\hline
\end{tabular}

Obviously, the WP and IP models do not show any constraints in in the distribution of the categories shown in Table 4 since they operate at the word level. Therefore, they are able to distinguish between: 1) compound suffixes; 2) $\{+\kappa(\mathrm{a})\}$ as a part of the word root; and 3 ) words formed by the suffix $\{+\kappa(a)\}$. However, the IA model deals with these words at the morpheme level; the correlation of the base and surface word is absent. Therefore, this model treats all words ending in $\{+\kappa(a)\}$ as havin been formed only by the suffix $\{+\kappa(a)\}$ relying on a juxtaposition of one morpheme to another.

Morphologically, we have seen that words formed by the suffix $\{+\kappa(a)\}$ may be subject to various linguistic phenomena, such as allomorphy, truncation and mutation. In addition, some words may take on more than one potential base. Thus, morphological models vary in their treatment of these phenomena. This disparity can be illustrated in Table 5: 
Table 5 Comparative view towards different phenomena

\begin{tabular}{lllllll}
\hline & Simple formation & Truncation & Allomorphy & Mutation & One base & Multiple bases \\
\hline WP & $\sqrt{ }$ & $\sqrt{ }$ & $\sqrt{ }$ & $\sqrt{ }$ & $\sqrt{ }$ & $\sqrt{ }$ \\
IP & $?$ & $\sqrt{ }$ & $\sqrt{ }$ & $\sqrt{ }$ & $\sqrt{ }$ & $?$ \\
IA & $\sqrt{ }$ & $?$ & $?$ & $?$ & $\sqrt{ }$ & $?$ \\
Frequency & 0.36 & 0.38 & 0.09 & 0.17 & 0.80 & 0.20 \\
\hline
\end{tabular}

The WP model explains all the above phenomena, whereas other models do not. Two main streams exist in the IP model: the first one assumes that WFRs operate only between words as suggested in the accounts put forward by e.g. Aronoff (1976), Stump (2001). In contrast, the second one supposes that these rules only operated on the word stem and so explain why certain phonemes are truncated, mutated, and altered during the formation of words as proposed in the theories put forward by, e.g., Matthews (1974), Anderson (1992). Thus, simple formation, which is triggered by an additive morphology cannot be explained by the latter theories because their stem does not contain any phonological (allomorphy and mutation) or morphological (truncation) processes to be described and explained later.

Also, it seems difficult to trace the base of surface words in the case of their having multiple potential bases when considering WFRs operate only between the stems themselves. Similarly, the IA model seems only able to explain the simple formation since it occurs in a linear arrangement. Other phenomena tend to be problematic for this model because the arbitrary correspondence of meaning and form caused by the occurrence of linguistic phenomena (e.g. allomorphy, truncation, and mutation) would violate the main concept of this model. Additionally, when we have a multiplicity of bases, the IA model has a deficiency in choosing a certain base for a certain surface word since it deals with words on the morpheme level.

Semantically, we have found that words formed by the suffix $\{+\kappa(a)\}$ often take on a semantic relevance to their bases, or sometimes they diverge from them. Moreover, these formations may either indicate one meaning or they are considered to be polysemous words. Some models may have problems in coping with this semantic correlation and the polysemy of meanings. This is described in Table 6:

Table 6 Comparative view towards semantic relevance

\begin{tabular}{llllll}
\hline & Match & Modify & Diverge & One meaning & Polysemous meanings \\
\hline WP & $\sqrt{ }$ & $\sqrt{ }$ & & $\sqrt{ }$ & $\sqrt{ }$ \\
IP & $\sqrt{ }$ & $?$ & $?$ & $\sqrt{ }$ & $?$ \\
IA & $\sqrt{ }$ & $?$ & $?$ & $\sqrt{ }$ & $?$ \\
Frequency & 0.17 & 0.13 & 0.10 & 0.78 & 0.22 \\
\hline
\end{tabular}

Again, the WP model does not show any restrictions in its treatment pertaining to the semantic correlation between related words whether they match, modify, or diverge from their bases. Contrary to this, IP and IA models manifest constraints towards these points. Similar problems reoccurred again for the IP model when taking into account the accounts put forward by, e.g. Matthews (1974), Anderson (1992). WFRs only operate between stems, so there is no way of explaining why words may be modified, diverged semantically or have polysemous meanings. Similarly, the IA model tends to be able to cover only two meaning 
constellations in Table 6 ('Match' and 'One meaning'). However, other constellations cannot be explained since it mismatches the main concept of this model which says that the morpheme is a representative of meaning and form simultaneously.

\section{Conclusion}

Derivational morphology is inclined to a canonicity by which the elements of form and meaning correspond to each other to a certain degree: a full morpho-semantic correlation regularly occurs. However, heterogeneity of meaning and form might occur to infringe the semantic correlation between related words. Thus, the morpheme-based approach seems insufficient for the classification of words in relation to their bases. Instead, the theoretical framework of a word-based approach is based on the connection of surface words to their base. This connection is divided into two levels: phonological and semantic. Consequently, this approach seems solid in classifying words with regard to their morphological source regardless of whether there is morpho-semantic correspondence or whether one of these corresponding elements is lost. This approach describes the relationships between the parent and derivative words as interrelated connection. Thus, this paradigmatic depiction simply represents a network of mutual relationships between surface and base words. This illustrates the degree of phonological and semantic similarity that exists between derivative elements. Subsequently, using this approach has highlighted the following issues:

1. Words containing the suffix $\{+\kappa(\mathrm{a})\}$ reflect a complex formation in which various linguistic phenomena have been identified in these formations. This complexity makes this suffix a good example to examine which approach is more suited to cover the entirety of word formation. This makes our analysis worthwhile as it can provide sufficient information that can be used as a guide for other formations in Russian.

2. The morpheme-based approach is insufficient when trying to link words to their base. However, the word-based approach proves its validity to cover all formations with the suffix $\{+\kappa(a)\}$ represented by the WP model.

3. Just because a word ends in a certain morpheme such as $\{+\kappa(\mathrm{a})\}$, does not always mean that it has been formed with that morpheme unless the correlation between the base and surface words is exposed. Thus, we have identified two other categories alongside the above suffix: 1) compound suffixes and 2) $\{+\kappa(a)\}$ as a part of the word root. This underlines the fact that the correlation between the base and surface word is: 1) fundamental, 2) undeniable, and 3) unavoidable.

4. Various word classes form words using the suffix $\{+\kappa(a)\}$. This emphasises that not only does the base select the affix, but it also determines the derivative word's meaning / function. This gives us a clear insight into how the word class of the base (noun, verb, adjective, etc.) can contribute to how and in what function the suffix $\{+\kappa(a)\}$ is used.

5. Formations of $\{+\kappa(a)\}$ have led to some theoretical assumptions that consider derivational morphology to be unpredictable due to its environment and that state it cannot obtain a high semantic relevance to be refuted. Our data has shown that the suffix $\{+\kappa(a)\}$ is predictable to the speaker by its use and it obtains a high semantic relevance compared to its base form.

Open Access This article is distributed under the terms of the Creative Commons Attribution 4.0 International License (http://creativecommons.org/licenses/by/4.0/), which permits unrestricted use, distribution, and reproduction in any medium, provided you give appropriate credit to the original author(s) and the source, provide a link to the Creative Commons license, and indicate if changes were made. 


\section{References}

Akademičeskij slovar' (1957): Slovar' russkogo jazyka v 4-x tomax. Tom 1: A-J (pod red. A. P. Evgen'eva). Moskva.

Akademičeskij slovar' (1958): Slovar' russkogo jazyka v 4-x tomax. Tom 2: K-O (pod red. G. P. Knjazykova, T. N. Popovceva, M. N. Sudoplatova). Moskva.

Anderson, S. R. (1992). A-morphous morphology (Cambridge Studies in Linguistics, 62). Cambridge.

Antić, E. (2010). The representation of morphemes in the Russian lexicon. $\mathrm{PhD}$ dissertation, University of California, Berkeley.

Aronoff, M. (1976). Word formation in generative grammar. Cambridge.

Bauer, L. (1988). Introducing linguistic morphology. Edinburgh.

Beard, R. (1988). On the separation of derivation from morphology. Toward a lexeme/morpheme based morphology. Quaderni di Semantica, 9, 3-59.

Beard, R. (1995). Lexeme-morpheme base morphology: a general theory of inflection and word formation. Albany.

Blevins, J. P. (2001). Paradigmatic derivation. Transactions of the Philological Society, 99(2), 211-222.

Booij, G. (2000). Inflection and derivation. In G. E. Booij, C. Lehmann, \& J. Mugdan (Eds.), Morphology. An international handbook on inflection and word-formation (Handbooks of Linguistics and Communication Science, 17/1, pp. 360-369). Berlin, New York.

Brown, D., \& Hippisley, A. (2012). Network morphology. A defaults-based theory of word structure (Cambridge Studies in Linguistics, 133). Cambridge.

Bybee, J. L. (1985). Morphology. A study of the relation between meaning and form (Typological Studies in Language, 9). Amsterdam, Philadelphia.

Bybee, J. L. (1988). Morphology as lexical organization. In M. Hammond \& M. Noonan (Eds.), Theoretical morphology. Approches in modern linguistics (pp. 119-141). San Diego.

Carstairs-McCarthy, A. (1987). Allomorphy in inflexion. London.

Carstairs-McCarthy, A. (2002). An introduction to English morphology. Words and their structure. Edinburgh.

Chialant, D., \& Caramazza, A. (1995). Where is morphology and how is it processed? The case of written word recognition. In L. B. Feldman (Ed.), Morphological aspects of language processing (pp. 55-76). Hillsdale.

Croft, W., \& Cruse, A. (2004). Cognitive linguistics. Cambridge.

Cubberley, P. (1994). Handbook of Russian affixes. Columbus.

Danilenko, V. P. (1977). Russkaja terminologija. Opyt lingvističeskogo opisanija. Moskva.

Davis, M. H., van Casteren, M., \& Marslen-Wilson, W. D. (2003). Frequency effect in processing inflected Dutch nouns: a distributed connectionist account. In R. H. Baayen \& R. Schreuder (Eds.), Morphological structure in language processing (Trends in Linguistics. Studies and Monographs, 151, pp. 427-462). Berlin.

Dement'ev, A. A. (1959). Očerki po slovoobrazovaniju imen suščestvitel'nyx v russkom jazyke. Učenye zapiski Kujbyševskogo pedagogičeskogo universiteta, 27, 5-181.

Di Sciullo, A.-M., \& Williams, E. (1987). On the definition of the word (Linguistic Inquiry Monographs, 14). Cambridge.

Evans, V., \& Green, M. (2006). Cognitive linguistics. An introduction. Edinburgh.

Feldman, L. B. (1994). Beyond orthography and phonology: differences between inflections and derivations. Journal of Memory and Language, 33, 442-470.

Fillmore, C. J. (1988). The mechanism of 'Construction Grammar'. In S. Axmaker, A. Jaisser, \& H. Singmaster (Eds.), Berkeley Linguistic Society. Proceedings of the Fourteenth Annual Meeting. February 13-15, 1988 (pp. 35-55). Berkeley.

Gaeta, L. (2007). On the double nature of productivity in inflectional morphology. Morphology, 17, 181-205. https://doi.org/10.1007/s11525-007-9117-7.

Gafarova, R. I. (2010). Produktivnye i neproduktivnye suffiksy univerbov russkogo jazyka. Učenye zapiski Tavričeskogo nacional'nogo universiteta im. V. I. Vernackogo. Serija 'Filologija. Social'nye kommunikacii', 23(3), 127-135.

Giraudo, H., \& Grainger, J. (2000). Effects of prime word frequency and cumulative root frequency in masked morphological priming. Language and Cognitive Processes, 15(4-5), 421-444. https://doi.org/10.1080/01690960050119652.

Goldberg, A. E. (2006). Constructions at work. The nature of generalization in language. Oxford.

Gonnerman, L. M., Seidenberg, M. S., \& Andersen, E. S. (2007). Graded semantic and phonological similarity effects in priming. Evidence for a distributed connectionist approach to morphology. Journal of Experimental Psychology: General, 136, 323-345.

González Torres, E. (2010). The inflection-derivation continuum and the Old English suffixes $-a,-e,-o,-u$. Atlantis. Revista de la Asociación Española de Estudios Ingleses y Norteamericanos, 32(1), 103-122. 
Greenberg, J. H. (1954). A quantitative approach to the morphological typology of language. In R. F. Spencer (Ed.), Method and perspective in anthropology. Papers in honor of Winson D. Wallis (pp. 192-220). Minneapolis.

Haspelmath, M. (2002). Understanding morphology. London.

Hathout, N., \& Namer, F. (2014). Discrepancy between form and meaning in word-formation. The case of over- and under-marking in French. In F. Rainer, F. Gardani, H. C. Luschützky, \& W. U. Dressler (Eds.), Morphology and meaning. Selected papers from the 15th International Morphology Meeting, Vienna, February 2012 (Amsterdam Studies in the Theory and History of Linguistic Science. Series, IV. Current Issues in Linguistic Theory, 327, pp. 177-190). Amsterdam.

Hippisley, A. (1996). Russian expressive derivation: a network morphology account. The Slavonic and East European Review, 74(2), 201-222.

Ignatova, N. I., Lifšic, A. T., \& Guseva, A. P. (Eds.) (1960). Grammatika russkogo jazyka. Fonetika i morfologija. Moskva.

Jacob, G., Fleischhauer, E., \& Clahsen, H. (2013). Allomorphy and affixation in morphological processing: a cross-modal priming study with late bilinguals. Bilingualism: Language and Cognition, 16(4), 924933.

Janda, L. A. (1993). A geography of case semantics. The Czech dative and the Russian instrumental (Cognitive Linguistics Research, 4). Berlin, New York.

Katamba, F. (1993). Morphology. Basingstoke, New York.

Kiparsky, P. (1982). Lexical morphology and phonology. In The Linguistic Society of Korea (Ed.), Linguistics in the morning calm. Selected papers from SICOL-1981 (pp. 3-91). Seoul.

Koefoed, G., \& van Marle, J. (2000). Productivity. In G. Booij, C. Lehmann, \& J. Mugdan (Eds.), Morphology. An international handbook on inflection and word-formation, $17 / 1$ (pp. 303-310)). Berlin, New York.

Lakoff, G. (1987). Women, fire, and dangerous things. What categories reveal about the mind. Chicago.

Langacker, R. W. (2002). Concept, image, and symbol. The cognitive basis of grammar (Cognitive Linguistics Research, 1). Berlin, New York.

Lazov, M. V. (Ed.) (1974). Obratnyj slovar' russkogo jazyka. Moskva.

Lenngren, L. (1978). Russkie derivacionnye suffiksy (Studia Slavica Upsaliensia, 19). Stockholm.

Lieber, R. (1980). On the organization of the lexicon (Doctoral dissertation, Massachusetts Institute of Technology). Cambridge.

Longtin, C.-M., \& Meunier, F. (2005). Morphological decomposition in early visual word processing. Journal of Memory and Language, 53(1), 26-41.

Longtin, C.-M., Segui, J., \& Hallé, P. A. (2003). Morphological priming without morphological relationship. Language and Cognitive Processes, 18(3), 313-334.

Marslen-Wilson, W., Tyler, L. K., Waksler, R., \& Older, L. (1994). Morphology and meaning in the English mental lexicon. Psychological Review, 101(1), 3-33.

Matthews, P. H. (1974). Morphology. An introduction to the theory of word-structure. Cambridge.

McCormick, S. F., Rastle, K., \& Davis, M. H. (2008). Is there a 'fete' in 'fetish'? Effects of orthographic opacity on morpho-orthographic segmentation in visual word recognition. Journal of Memory and Language, 58, 307-326. https://doi.org/10.1016/j.jml.2007.05.006.

McMahon, A. M. S. (1994). Lexical phonology and morphology. In R. E. Asher (Ed.), The encyclopedia of language and linguistics. Vol. 4 (pp. 2155-2160). Oxford.

Miceli, G., \& Caramazza, A. (1988). Dissociation of inflectional and derivational morphology. Brain and Language, 35, 24-65.

Mohanan, K. P. (1985). Syllable structure and lexical strata in English. Phonology, 2, 139-155.

Mohanan, K. P. (1986). The theory of lexical phonology. Dordrecht.

Östman, J.-O., \& Fried, M. (2005). Construction grammars. Cognitive grounding and theoretical extensions (Constructional Approaches to Language, 3). Amsterdam, Philadelphia.

Ožegov, S. I., \& Švedova, N. Ju. (1995). Tolkovyj slovar' russkogo jazyka. Moskva.

Pesetsky, D. (1985). Morphology and logical form. Linguistic Inquiry, 16(2), 193-246.

Plag, I. (1996). Selectional restrictions in English suffixation revisited: a reply to Fabb (1988). Linguistics, 34, 769-798.

Plaut, D. C., \& Gonnerman, L. M. (2000). Are non-semantic morphological effects incompatible with a distributed connectionist approach to lexical processing? Language and Cognitive Processes, 15(4-5), 445485. https://doi.org/10.1080/01690960050119661.

Potixa, Z. A. (1970). Sovremennoe russkoe slovoobrazovanie. Moskva.

Rastle, K., \& Davis, M. H. (2003). Reading morphologically complex words: some thoughts from masked priming. In S. Kinoshita \& S. J. Lupker (Eds.), Masked priming. The state of the art (pp. 279-305). New York.

Rastle, K., \& Davis, M. H. (2008). Morphological decomposition based on the analysis of orthography. In R. Frost, J. Grainger, \& M. Carreiras (Eds.), Advances in morphological processing [Special issue]. Language and Cognitive Processes, 23(7-8), 942-971. 
Rastle, K., Davis, M. H., Marslen-Wilson, W. D., \& Tyler, L. K. (2000). Morphological and semantic effects in visual word recognition: a time-course study. Language and Cognitive Processes, 15(4-5), 507-537.

Rastle, K., Davis, M. H., \& New, B. (2004). The broth in my brother's brothel: morpho-orthographic segmentation in visual word recognition. Psychonomic Bulletin \& Review, 11(6), 1090-1098.

Rueckl, J. G., \& Raveh, M. (1999). The influence of morphological regularities on the dynamics of a connectionist network. Brain and Language, 68(1-2), 110-117.

Ryazanova-Clarke, L., \& Wade, T. (1999). The Russian language today. London.

Shanskii, N. M. (1968). Russian word formation (transl. by B. S. Johnson). Oxford.

Shopen, T. (1985). Language typology and syntactic description. Volume 3: Grammatical categories and the lexicon. Cambridge.

Šmelev, D. N. (1964). O semantičeskix izmenenijax v sovremennom russkom jazyke. In I. P. Mučnik \& M. V. Panov (Eds.), Razvitie grammatiki i leksiki sovremennogo russkogo jazyka (pp. 4-17). Moskva.

Stump, G. T. (1993). How peculiar is evaluative morphology? Journal of Linguistics, 29(1), 1-36.

Stump, G. (1994). Review of: Bochner, H. (1993). Simplicity in generative morphology. Berlin, New York. Language, 70(3), 581-585. https://doi.org/10.2307/416494.

Stump, G. T. (1998). Inflection. In A. Spencer \& A. Zwicky (Eds.), The handbook of morphology (pp. 13-43). Oxford.

Stump, G. T. (2001). Inflectional morphology. A theory of paradigm structure (Cambridge Studies in Linguistics, 93). Cambridge.

Stump, G. T. (2016). Inflectional paradigms. Content and form at the syntax-morphology interface (Cambridge Studies in Linguistics, 149). Cambridge.

Taft, M., \& Forster, K. I. (1975). Lexical storage and retrieval of prefixed words. Journal of Verbal Learning and Verbal Behavior, 14(6), 638-647.

Townsend, C. E. (1975). Russian word-formation. Columbus.

Ukiah, N. (1996). Review of: T. Nesset (1994). Russian stress. Stress as an inflectional formative in Russian noun paradigms and Bybee's cognitive morphology. Oslo. Slavonic and East European Review, 74(4), 701-704.

Uluxanov, I. S. (1975). Otnošenie motivacii meždu glagolom i suščestvitel'nym so značeniem dejstvija. Voprosy jazykoznanija, 4, 38-45.

Ušakov, D. N. (Ed.) (1935-1940). Tolkovyj slovar' russkogo jazyka. Moskva.

Vinogradov, V. V. (1951). Voprosy sovremennogo russkogo slovoobrazovanija v svete trudov I. V. Stalina po jazykoznaniju. Russkij jazyk $v$ škole, 2, 1-10.

Vinogradov, V. V., Istrina, E. S., \& Barxudarov, S. G. (1952). Grammatika russkogo jazyka. Moskva.

Zemskaja, E. A., \& Šmelev, D. N. (Eds.) (1966). Razvitie slovoobrazovanija sovremennogo russkogo jazyka. Moskva. 